Kinetic study of the pyrolysis of microalgae under nitrogen and $\mathrm{CO} 2$ atmosphere

Yu Hong, Chengrui Xie, Wanru Chen, Xiang Luo, Kaiqi Shi, Tao Wu

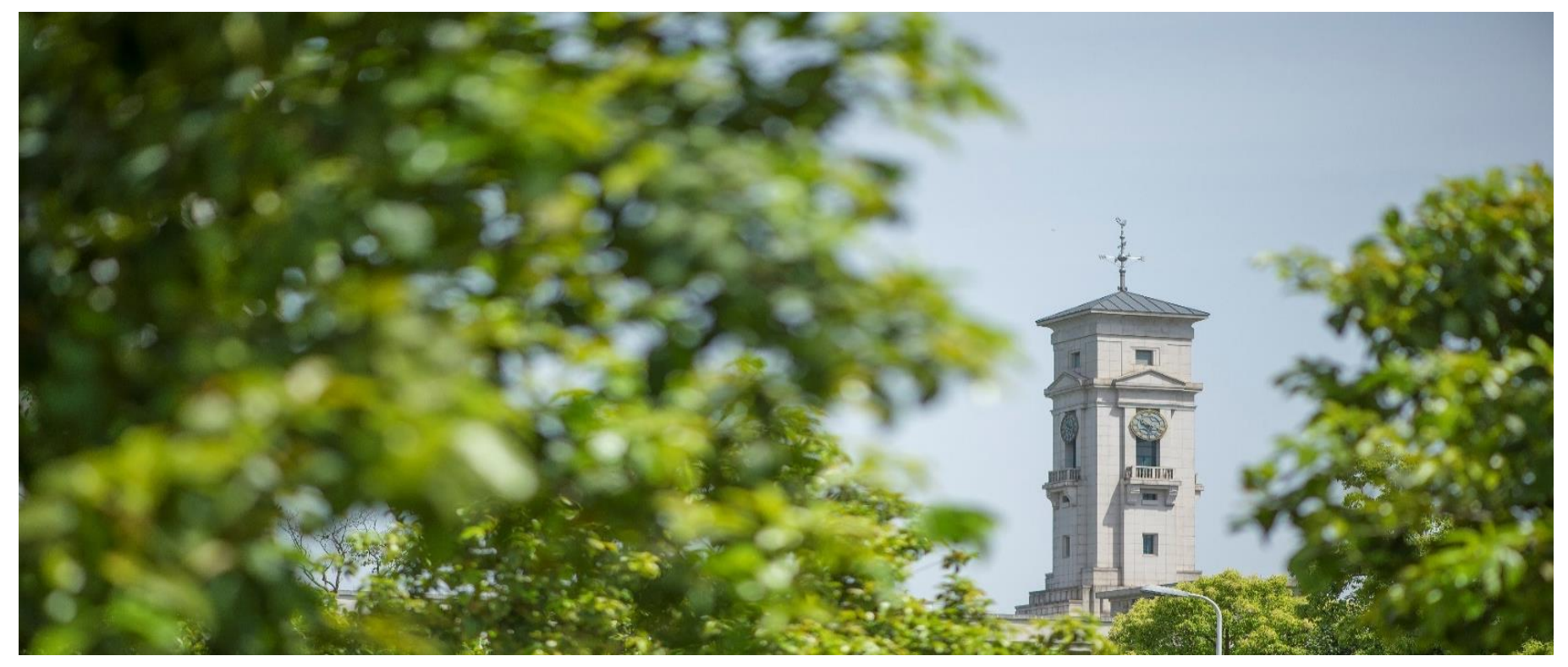


University of Nottingham Ningbo China, 199 Taikang East Road, Ningbo, 315100, China

First published 2019

This work is made available under the terms of the Creative Commons Attribution 4.0 International License:

http://creativecommons.org/licenses/by/4.0

The work is licenced to the University of Nottingham Ningbo China under the Global University Publication Licence:

https://www.nottingham.edu.cn/en/library/documents/researchsupport/global-university-publications-licence.pdf Nottingham 


\section{Kinetic study of the pyrolysis of microalgae under nitrogen and $\mathrm{CO}_{2}$} atmosphere

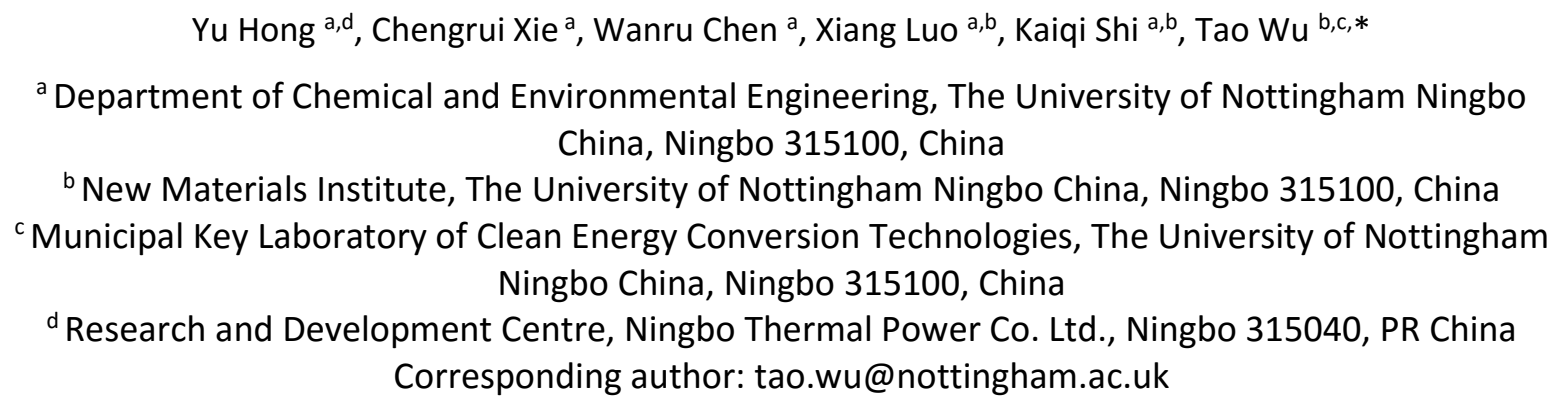

\section{Abstract}

In this study, three primary components of algae (lipid, carbohydrate and protein) and one microalgae (spirulina) were pyrolyzed in a thermogravimetric analyzer (TGA) under nitrogen and $\mathrm{CO}_{2}$ atmosphere at four heating rates. It was found that protein decomposed first, which was followed by carbohydrate and then lipid. Kinetic study revealed that ovalbumin (protein) had the lowest activation energy of $\sim 70 \mathrm{~kJ} / \mathrm{mol}$ for the initiation of pyrolysis. Oil droplet showed higher activation energy of $266.5 \mathrm{~kJ} / \mathrm{mol}$ in $\mathrm{CO}_{2}$ atmosphere, which suggests that algal lipid is more difficult to decompose in $\mathrm{CO}_{2}$ atmosphere. However, for the pyrolysis of cellulose (carbohydrate), the activation energy $(\sim 310 \mathrm{~kJ} / \mathrm{mol})$ was similar under two different gas atmospheres tested. This study showed that $\mathrm{CO}_{2}$ atmosphere favors the pyrolysis of algae with high protein content and low lipid content, since the existence of $\mathrm{CO}_{2}$ promotes the cracking of VOCs as well as the reaction between VOCs and $\mathrm{CO}_{2}$.

Keywords: Kinetics; Pyrolysis; Algae; Model compounds; Carbon dioxide

\section{Introduction}

As a renewable carbonaceous resource, marine biomass has recently attracted special interests and is regarded as a potential substituent to traditional fuels. The terrestrial biomass is primarily comprised of cellulose, hemicellulose and lignin [1], while algal biomass 
29 consists of carbohydrates, proteins, and lipids, which has been investigated by many

30 researchers on its conversion to various biofuels [2-6].

31 Two different approaches, i.e. thermogravimetric analysis (TGA) and differential

32 thermogravimetric analysis (DTG), are commonly used to study the thermal decomposition

33 of algae and its model components. Numerous research was focused on the thermal

34 degradation of biomass via the observation of weight change with temperature [7-9]. Two

35 commonly-used iso-conversional methods, i.e. Kissinger-Akahria-Sunose (KAS) and Flynn-

36 Wall-Ozawa (FWO), were applied to conduct kinetic analysis of pyrolysis and thus to

37 determine parameters including activation energy $\left(E_{a}\right)$ and pre-exponential factor $(A)[8,10$,

38 11]. However, the decomposition of different components in biomass leads to extremely

39 complicated pyrolysis process, which makes the iso-conversional method relatively

40 inappropriate [12]. More commonly, the model fitting method is used to simulate the

41 kinetics of biomass pyrolysis by substituting different reaction models into Coats-Redfern

42 function. The highest regression value of such indicates the best mechanism model for the

43 pyrolysis event [13].

44 The conventional pyrolysis of biomass and the kinetic study have been discussed in many

45 previous studies $[8,10,12,14-16]$. It is reported that compared with $\mathrm{N}_{2}$, the use of $\mathrm{CO}_{2}$ as

46 the carrier gas could assist the pyrolysis of carbonaceous materials and lead to some

47 benefits such as higher thermal efficiency, reduced tar formation, higher production of

48 syngas (especially CO), etc. $[17,18]$. However, there is not much work that has been carried

49 out on the kinetics of the pyrolysis of algal model compounds under carbon dioxide 
50 atmosphere, as well as the comparison of the results produced under these two different

51 atmospheres.

52 In this study, kinetic study of the pyrolysis of three model compounds, i.e., carbohydrate,

53 lipid and protein, and microalgae- spirulina under $\mathrm{N}_{2}$ and $\mathrm{CO}_{2}$ atmospheres was conducted.

54 Iso-conversional method (Kissinger- Akahira-Sunose method) and model fitting method

55 (Coats-Redfern method) were applied to derive the activation energy $\left(E_{a}\right)$ and pre-

56 exponential factor (A). The parameters and EDS analysis of the composition of char

57 obtained under $\mathrm{N}_{2}$ and $\mathrm{CO}_{2}$ atmosphere were also compared to reveal the pyrolysis of algae.

\section{Material and Methods}

\section{$59 \quad 2.1 \quad$ Materials}

60 Oil droplet (Optima 339 powdered vegetable fat), $\alpha$-Cellulose $\left(\left(\mathrm{C}_{6} \mathrm{H}_{10} \mathrm{O}_{5}\right)_{n}\right.$, Aladdin ${ }^{\circledR}$,

61 product code C104844) and ovalbumins (Sinopharm Chemical Reagent Co., Ltd, product

62 code 69003835) were selected to represent and simulate the pyrolysis of lipid,

63 carbohydrate, protein contents in algae, respectively, which followed the approach used by

64 other researchers [19-21]. Spirulina, the algae sample, was provided by Shandong Binzhou

65 Tianjian Biotechnology Co. Ltd. (Shandong Province, China). Raw materials were milled

66 (Retsch ZM200 Ultra-Centrifugal mill) and sieved to the same particle size of less than 120

$67 \mu \mathrm{m}$. 


\subsection{Characterization of algae primary model compounds}

69 The results of proximate, elemental and composition analyses are listed in Error! Reference

70

71

72

73

74

75

76

77

78

79

80

81

82

83

84

85

86

87

source not found., the procedure can be find in our previous studies [22-25]. The compositions of protein, lipid and carbohydrate in biomass were determined by Kjeldahl method (BS EN ISO 20483:2013), Soxhlet extraction (GB/T 5009.6-2003), and the difference calculated (GB/Z 21922-2008), respectively.

\subsection{Kinetic analysis method}

Pyrolysis of three algal pseudo-components and spirulina via conventional electric heating method was conducted on a thermogravimetric analyser (TGA, NETZSCH STA449F3, Germany) using non-isothermal process. Four different heating rates, i.e., 5, 10, 20 and $50^{\circ} \mathrm{C} / \mathrm{min}$, were used to heat the samples from 50 to $900^{\circ} \mathrm{C}$. The weight loss profile of each sample was subsequently derived. Pure nitrogen or carbon dioxide with a flowrate of $20 \mathrm{~mL} / \mathrm{min}$ was introduced into the system as carrier gas and to provide an oxygen-free atmosphere. The initial sample weight for each experiment was $2 \pm 0.5 \mathrm{mg}$. All experiments were repeated at least once to ensure accuracy and repeatability.

In order to investigate the effects of $\mathrm{CO}_{2}$ on the carbon contained in solid residue, char samples were first prepared in a tube furnace (SG-GL1200K, Shanghai) using the same TGA heating programme, i.e. all samples were heated from 50 to $900{ }^{\circ} \mathrm{C}$ with a heating rate of $5^{\circ} \mathrm{C} / \mathrm{min}$ under a $\mathrm{N}_{2}$ purge of $20 \mathrm{~mL} / \mathrm{min}$. The char samples collected were then subject to kinetic analysis (in $\mathrm{CO}_{2}$ ) via the same procedure in TGA described previously. 


\subsubsection{Determination of Kinetic Parameters}

89 The thermal decomposition of algae is a typical solid decomposition reaction, the rate of 90 which is defined as Eq. (a),

$91 \alpha=\frac{m_{0}-m_{\top}}{m_{0}-m_{f}}$

Eq. (a)

92 Where $m_{0}$ is the initial mass of the material, $m_{f}$ is the final mass of the solid material after

93 pyrolysis, $m_{T}$ is the mass of material at reaction temperature of $\mathrm{T}$.

94 The kinetic study is based on the Arrhenius law. According to Eq. (a), the conversion rate

95 only depends on the reaction temperature. The thermal dynamic formula can be described

96 as Eq. (b),

$97 \quad \frac{d \alpha}{f(\alpha)}=\frac{A}{\beta} \exp \left(\frac{-E_{a}}{R T}\right) d T$

98 Where $f(\alpha)$ is the conversion $(\alpha)$-dependent function; $\beta=\frac{d T}{d t}$ is the heating $\mathrm{rate}, \mathrm{K} / \mathrm{min}$;

$99 E_{a}$ is the activation energy, $\mathrm{J} / \mathrm{mol} ; \mathrm{A}$ is the pre-exponential factor, $\mathrm{min}^{-1}$; $\mathrm{R}$ is the universal

100 gas constant, $8.314 \mathrm{~J} / \mathrm{mol} \cdot \mathrm{K} ; \mathrm{T}$ is the absolute temperature, $\mathrm{K}$.

101 The integration of Eq. (b) over $\alpha$ is expressed as Eq. (c),

102

$G(\alpha)=\int_{0}^{\alpha} \frac{d \alpha}{f(\alpha)}=\frac{A}{\beta} \int_{0}^{T} \exp \left(\frac{-E_{a}}{R T}\right) d T$

Eq. (c)

103 Where $G(\alpha)$ is the integrated form of $f(\alpha)$. 
105 Generally, the activation energy and pre-exponential factor of one-step fluid state reactions 106 are constant, but these parameters would change depending on the conversion rate $(\alpha)$ for 107 reactions involving solid, due to its internal heterogeneity of solid samples and complicated 108 reaction mechanism [26]. Therefore, iso-conversional methods can be applied to determine 109 the kinetic parameters of solid state reactions.

110 KAS method is based on Arrhenius equation using differential method [26, 27],

$111 \quad G(\alpha)=\frac{A E_{a}}{\beta R} p\left(\frac{E_{a}}{R T}\right)$

112 Combined with eq. (c), the variables of $\mathrm{A}, \mathrm{E}_{\mathrm{a}}$ and $f(\alpha)$ are related to $\mathrm{T}$, whilst $\mathrm{A}$ and $\mathrm{E}_{\mathrm{a}}$ are 113 independent of $\alpha$. Hence, Eq. (c) can be further integrated into the following form,

$114 \quad \ln \frac{\beta}{T^{2}}=\ln \left(\frac{R A}{E_{a} G(\alpha)}\right)-\frac{E_{a}}{R T}$ Eq. (e)

115 The plot of $\ln \frac{\beta}{T^{2}}$ versus $-\frac{1}{R T}$ for constant $\alpha$ will derive a linear relationship.

116 In order to reveal the correlation between $\mathrm{E}_{\mathrm{a}}$ and $\alpha$ specifically, 19 conversion rates from 5

117 to $95 \%$ were selected. The $E_{a}$ can be determined by the gradient of the linear profile.

\subsubsection{Model fitting method: Coats-Redfern method}

119 The Coats-Redfern method is one of the model fitting approaches, which can be used to 120 calculate the kinetic parameters as well as to determine the order and mechanism of the 121 reaction[28].

122 Coats-Redfern approximation was applied and further rearranged as Eq. (f), 
$123 \quad \ln \frac{G(\alpha)}{T^{2}}=\ln \left[\frac{A R}{\beta E_{a}}\left(1-\frac{2 R T}{E_{a}}\right)\right]-\frac{E_{a}}{R T}$

Eq. (f)

124 The function $G(\alpha)$ depends on different reaction models [29].

125 The usual value of $\frac{2 R T}{E_{a}}$ is far less than 1, which can normally be disregarded. Therefore, the 126 equation could be simplified as Eq. (g),

$127 \ln \frac{G(\alpha)}{T^{2}}=\ln \left(\frac{A R}{\beta E_{a}}\right)-\frac{E_{a}}{R T}$

128 By substituting different forms of $G(\alpha)$ into Eq. (g), a plot of $\ln \frac{G(\alpha)}{T^{2}}$ versus $-\frac{1}{R T}$ is linear 129 with a slope equal to $E_{a}$ and the interception point provides values of $E_{a}$ and $A$.

\section{Results}

\section{$131 \quad 3.1$ Thermogravimetric analysis}

132 Previous workers have examined single reaction model, and multiple parallel reaction 133 model consisting up to seven-reactions based on different components or constituents in 134 algae with different reactivity [30]. In previous study, ovalbumin [19], cellulose [20], and oil 135 droplet [21] were used to represent protein, carbohydrate and lipid in algae, therefore, 136 these compounds were chosen in this study to represent the protein, carbohydrate and 137 lipid content in spirulina. The simulated TGA and DTG curves of spirulina were calculated 138 using the sum of each TGA and DTG data of three model compounds multiplied to the 139 corresponding composition of protein, carbohydrate, and lipid content in spirulina (Error!

140 Reference source not found.).As shown in Figures 1 and 2, the use of these three components 141 could simulate the actual alga with relatively satisfactory accuracy, the same as what was 
142 reported by other researcher [31, 32]. Multiple pyrolysis of algal model compounds,

143 spirulina, and the calculated data for spirulina at heating rates of $5,10,20$ and $50{ }^{\circ} \mathrm{C} / \mathrm{min}$

144 are illustrated in Figure 1 and

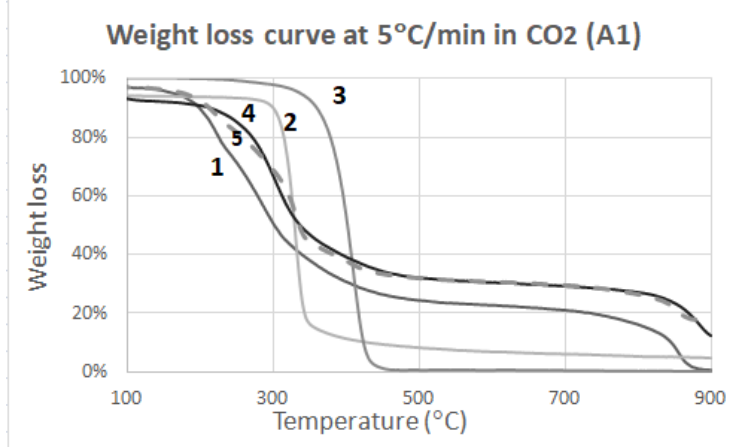

145
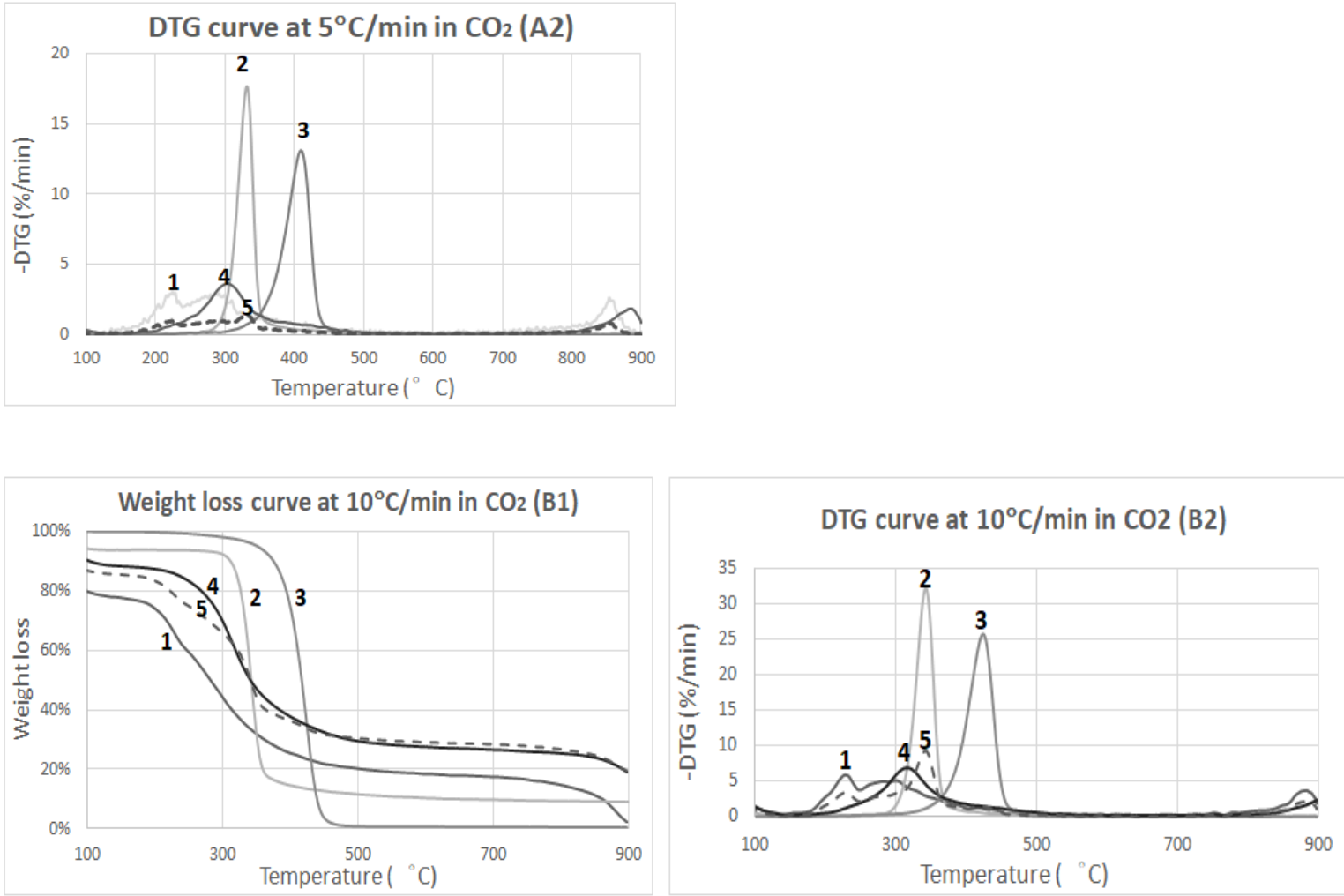

146 

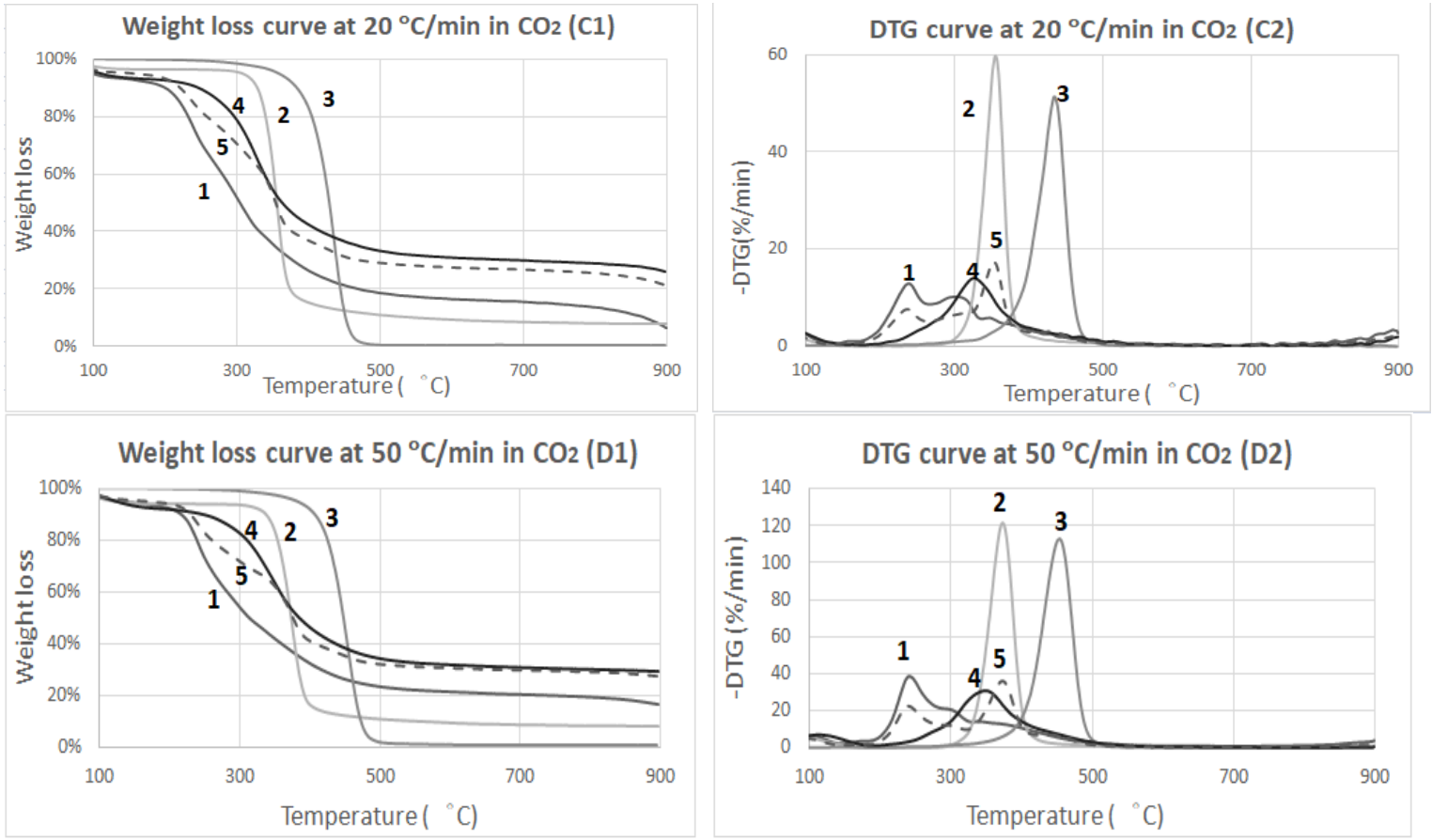

Figure 2, in order to reveal its mechanism [33]. Although the heating rates were different,

151 the TG curves were comparable with similar initial and final temperatures. However, the 152 peak value of DTG curve shifted to higher temperature zone as the heating rate increased 153 and reached the set maximum of $50{ }^{\circ} \mathrm{C} / \mathrm{min}$. This phenomenon is attributed to the 154 hysteresis in heat transfer from crucible to sample, as well as the difference in actual 155 temperature of the samples and that of the measured temperature of the crucible. 156 Moreover, the larger amount of volatile matter released with elevating heating rate. 157 Apparent from the comparison of DTG curves under $\mathrm{N}_{2}$ and $\mathrm{CO}_{2}$, ovalbumin showed higher 158 weight loss rate under $\mathrm{CO}_{2}$, whilst the rate of weight loss for oil droplet and cellulose 159 remained unchanged. 

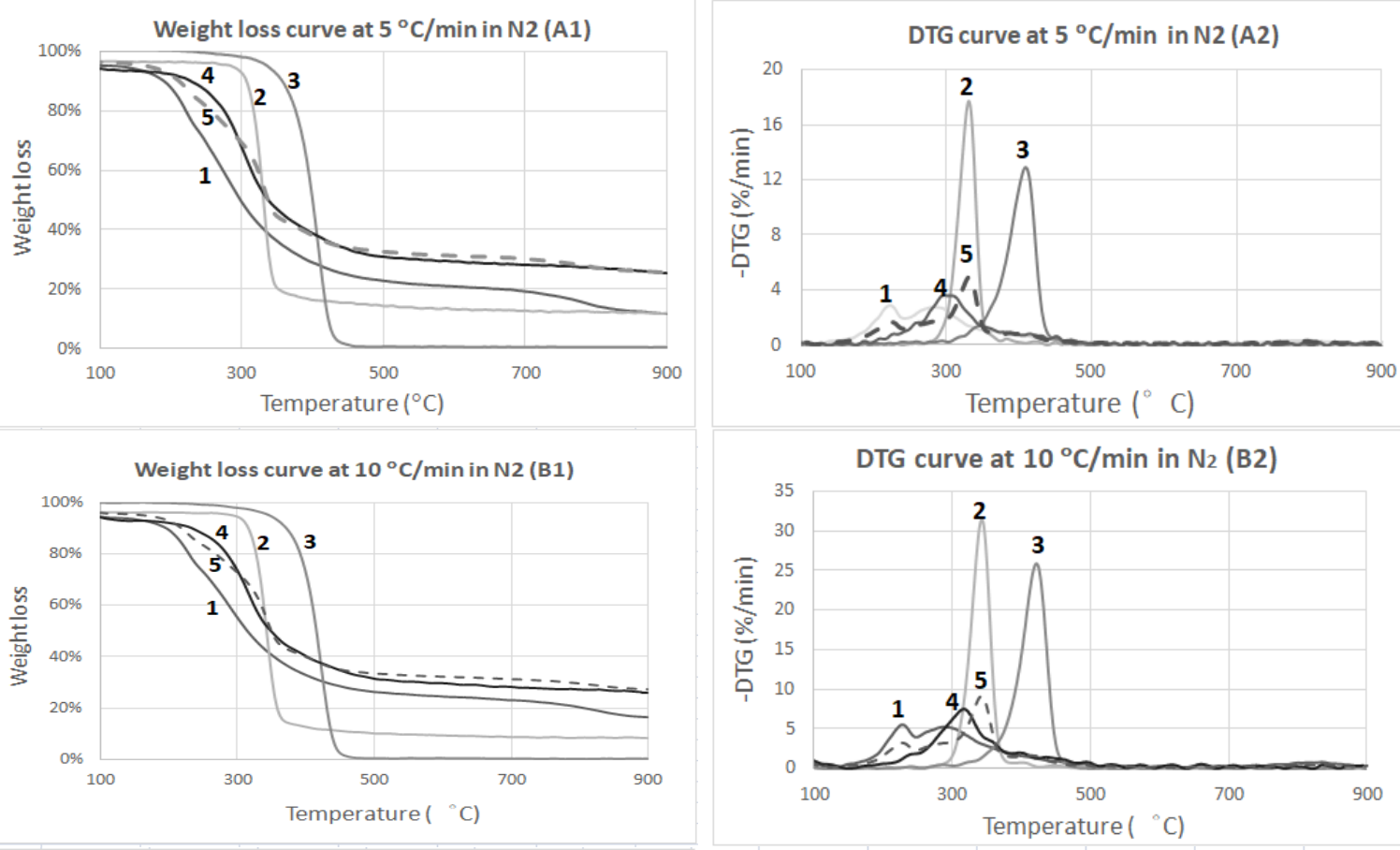

161
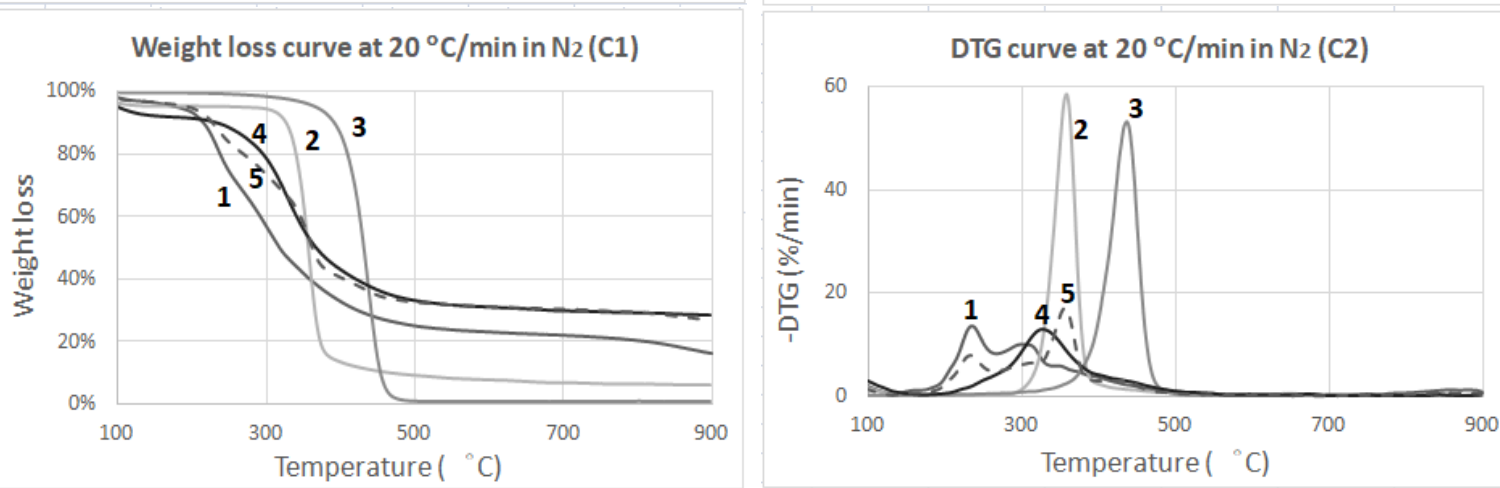

162
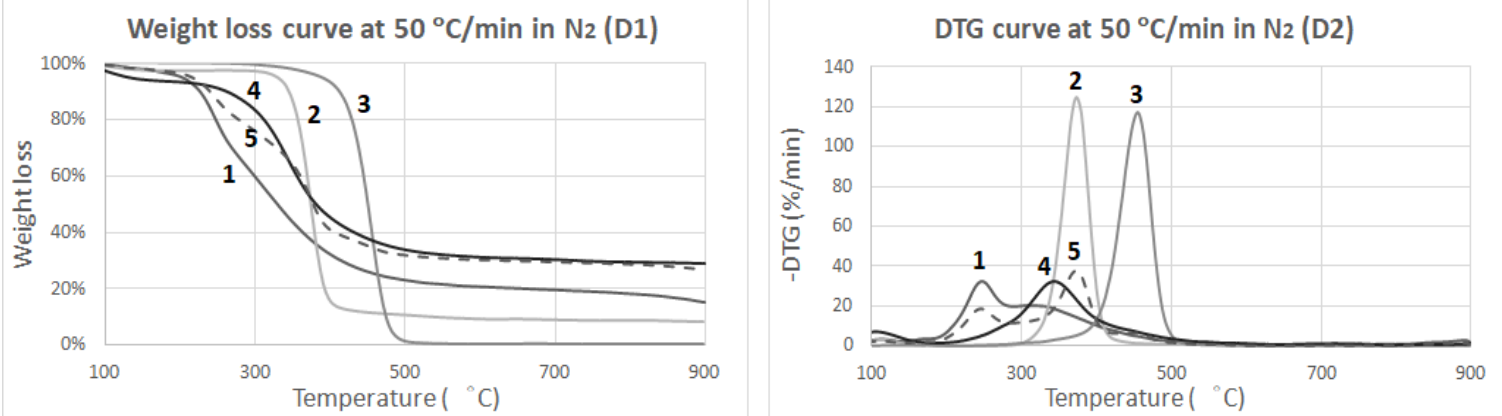

Figure 1 TG (1) and DTG (2) curves of the pyrolysis of ovalbumin (1), cellulose (2), oil 167 droplet (3), spirulina (4) and simulative spirulina (5) under $\mathrm{N}_{2}$ at different heating rates of 5 (A), 10 (B), 20 (C), and 50 (D) ${ }^{\circ} \mathrm{C} / \mathrm{min}$. 

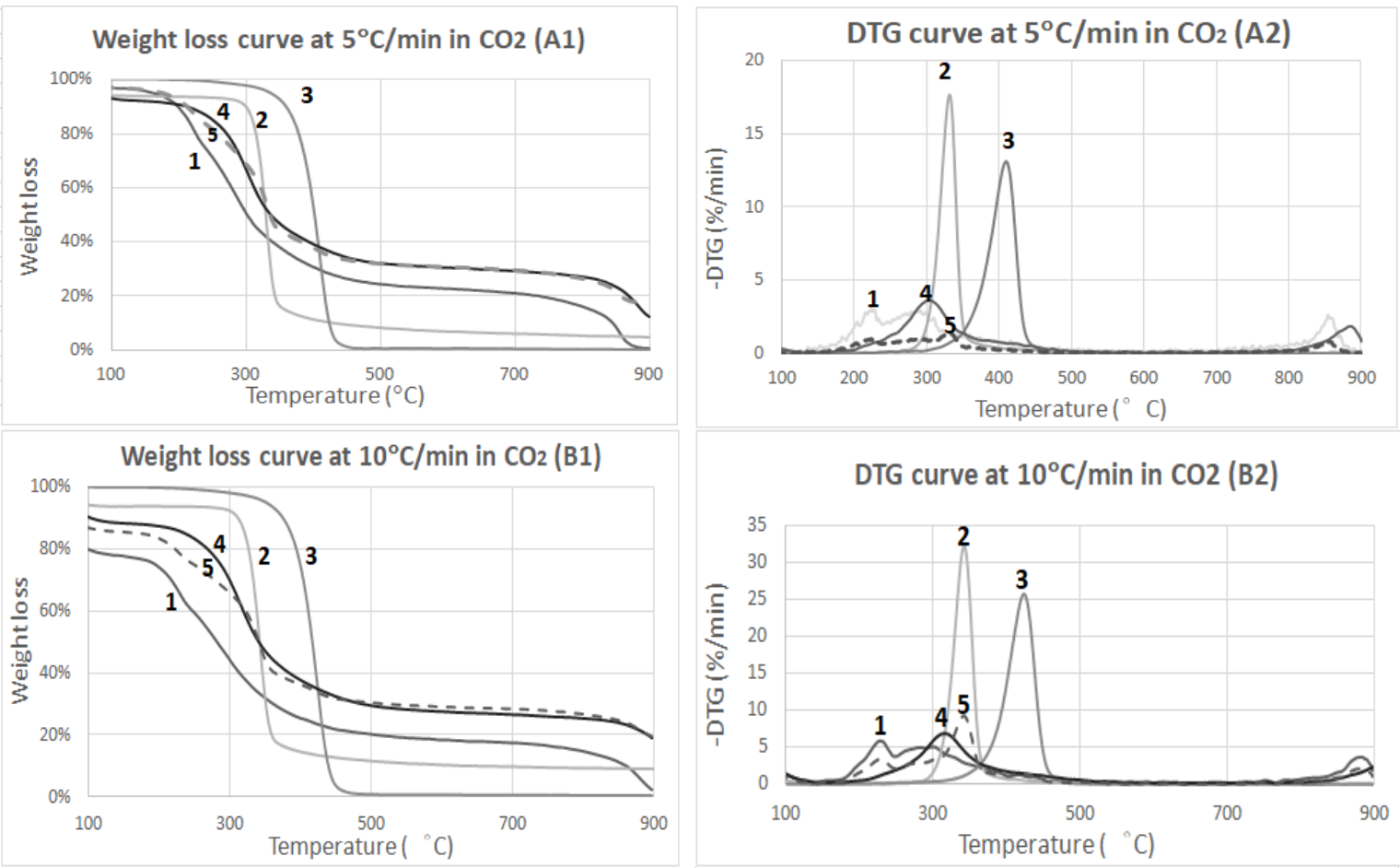

169
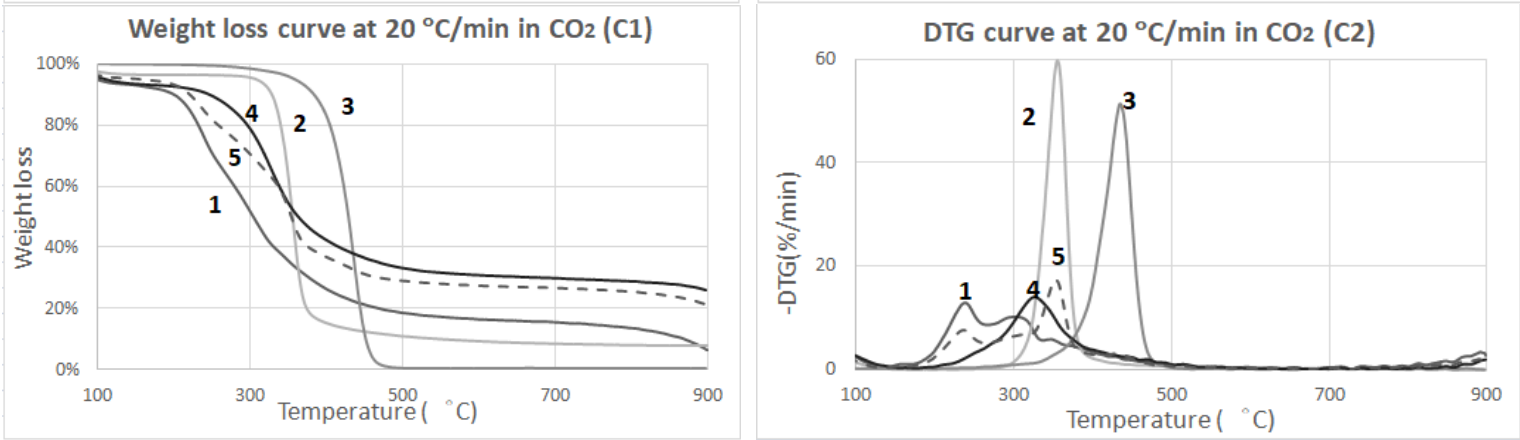

170
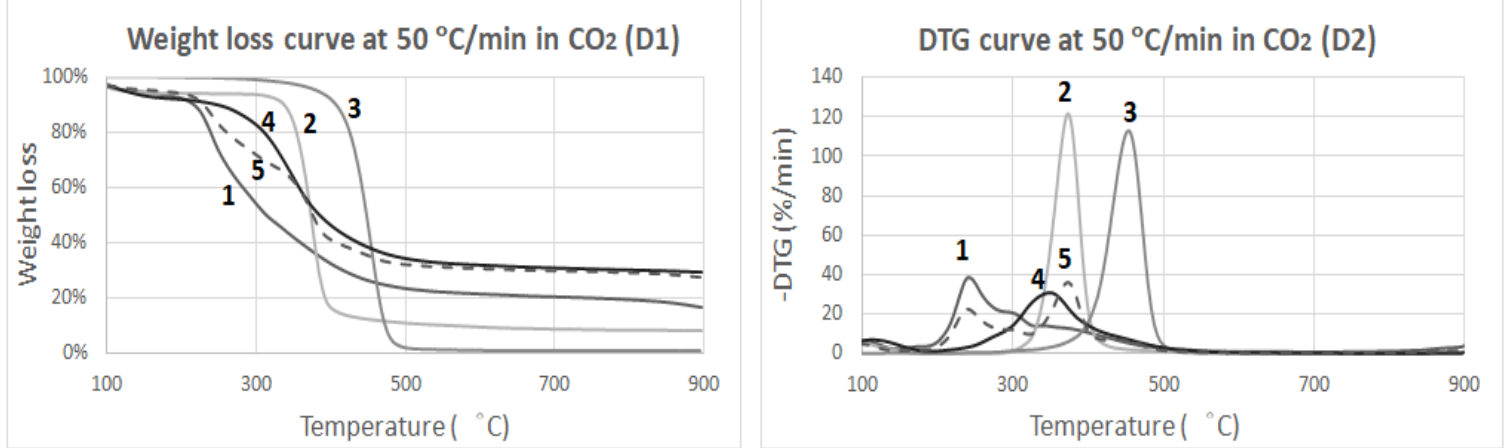

171

172

173

174

175

176
Figure 2 TG and DTG curves of the pyrolysis of ovalbumin (1), cellulose (2), oil droplet (3), spirulina (4) and simulativespirulina (5) under $\mathrm{CO}_{2}$ at different heating rates of 5 (A), 10 (B), 20 (C), and 50 (D) ${ }^{\circ} \mathrm{C} / \mathrm{min}$. 
177 Table 1 Characteristics of cellulose, ovalbumin, oil droplet and spirulina

\begin{tabular}{|c|c|c|c|c|}
\hline & Ovalbumin & Cellulose & Oil droplet & Spirulina \\
\hline \multicolumn{5}{|c|}{ Proximate analysis (wet basis, wt. \%) } \\
\hline Moisture content & 2.0 & 2.7 & 0 & 6.7 \\
\hline Volatile matters & 86.6 & 88.6 & 100.0 & 73.5 \\
\hline Fixed carbon & 9.9 & 7.6 & 0 & 13.2 \\
\hline Ash content & 0 & 1.1 & 0 & 6.6 \\
\hline \multicolumn{5}{|c|}{ Ultimate analysis (dry ash free basis, wt. \%) } \\
\hline C & 41.6 & 42.7 & 75.8 & 49.8 \\
\hline H & 7.0 & 6.5 & 11.8 & 6.6 \\
\hline N & 12.2 & 0 & 0 & 11.0 \\
\hline S & 1.2 & 0 & 0 & 0.7 \\
\hline O & 38.0 & 50.8 & 12.4 & 31.9 \\
\hline HHV (MJ/kg) & 18.73 & 16.99 & 39.07 & 20.55 \\
\hline \multicolumn{7}{|c|}{ Composition of sample (wt. \%) } \\
\hline Protein & 81.6 & 0 & 0 & 57.8 \\
\hline Lipid & 1.1 & 1.2 & 99.6 & 2.9 \\
\hline Carbohydrate & 7.9 & 97.1 & 0.1 & 23.4 \\
\hline
\end{tabular}

178

179

Figure

1

and

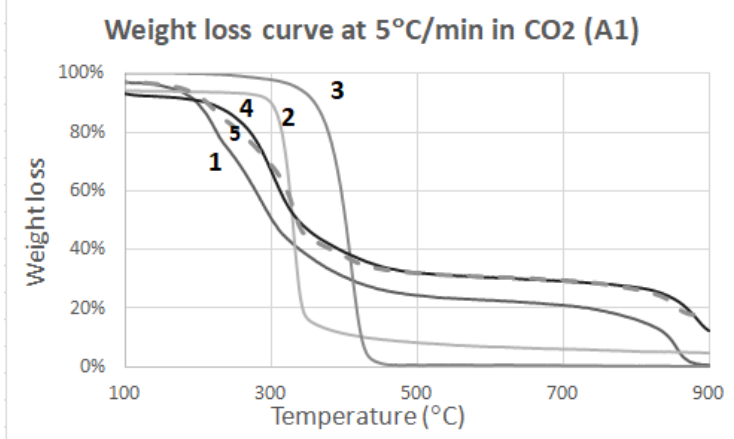


181
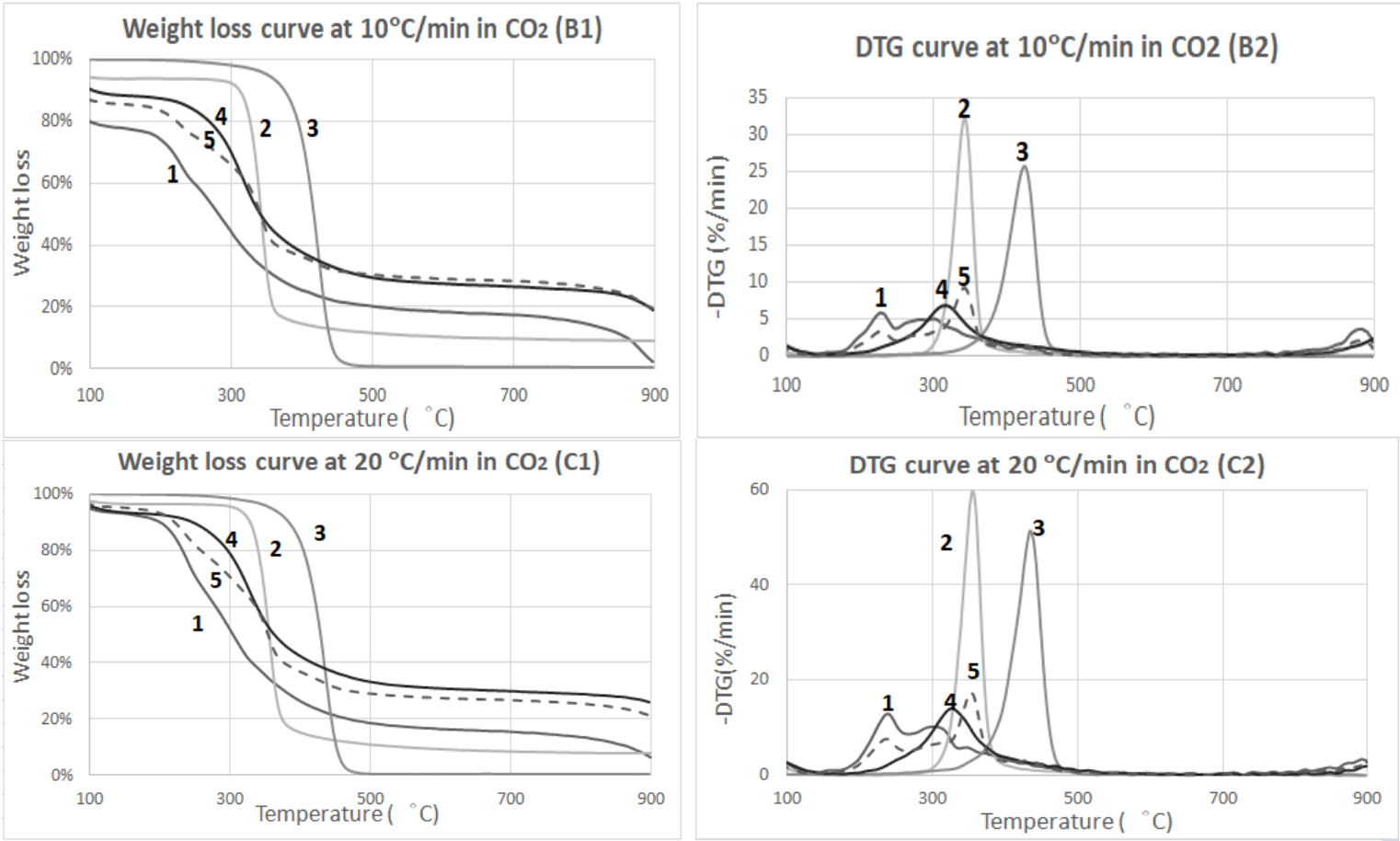

182
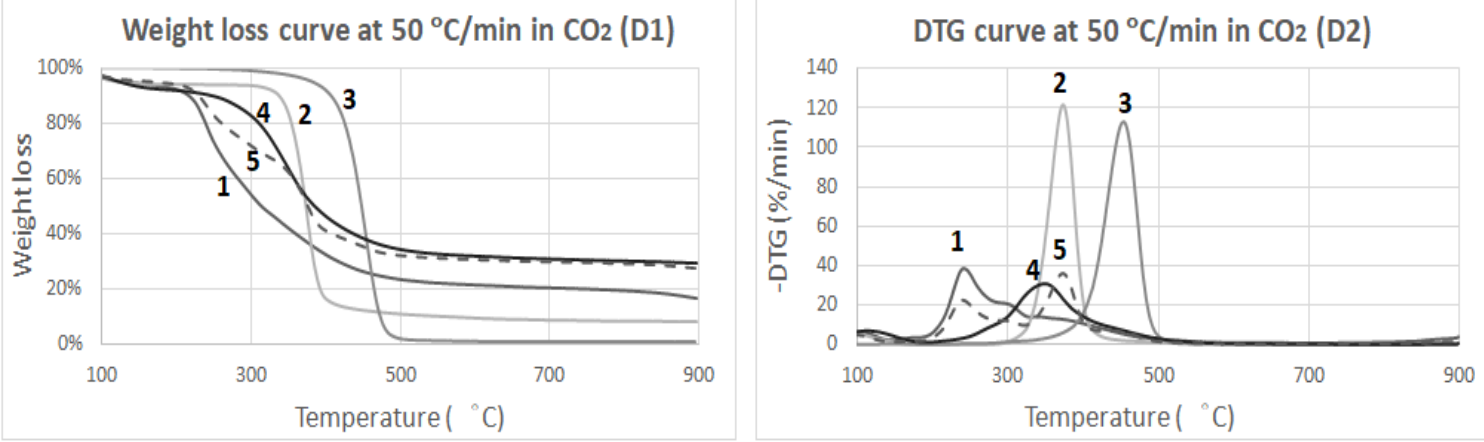

183

184

185

186

187

188

189

190

191

Figure 2 show that the degradation pattern of model compounds and algae were similar with three common stages involving dehydration, volatilization and carbonization under both $\mathrm{N}_{2}$ and $\mathrm{CO}_{2}$ atmospheres. The first stage started from ambient temperature to the temperature where light volatiles began to release, during which the moisture in biomass was removed at around $105^{\circ} \mathrm{C}$. Although only slight weight loss has been observed during this stage, the structure of sample has changed. A major weight loss was recorded in the second stage ranging from 150 to $500^{\circ} \mathrm{C}$, primarily due to the devolatilization of organic 

matters. Ovalbumin, cellulose, oil droplet and spirulina decomposed mainly in the 193 temperature range of $180-250,290-370,330-470$ and $220-400^{\circ} \mathrm{C}$, respectively. Given the 194 low decomposition temperature, it can be inferred that the protein and carbohydrate of 195 algae are of low thermal stability, whilst lipid is of high thermal stability under both 196 atmospheres. This waste losst is regarded as the main pyrolysis stage. The third stage (500$197800^{\circ} \mathrm{C}$ ) showed a steady weight loss which was resulted from the decomposition of non198 volatile carbonaceous residues. Char was formed whilst $\mathrm{CO}_{2}$ and $\mathrm{CO}$ were removed [34, 35].

As evident from Figure 1 and

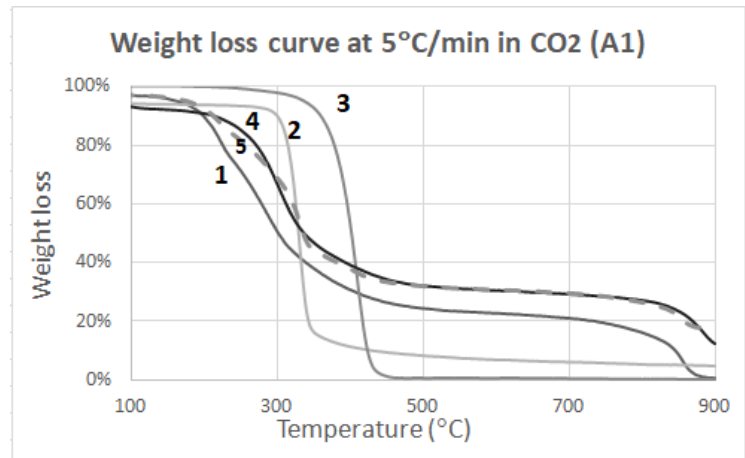

200

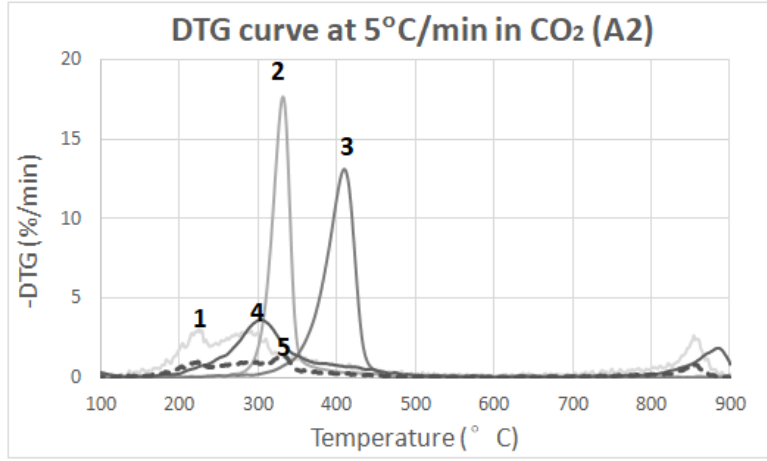


201
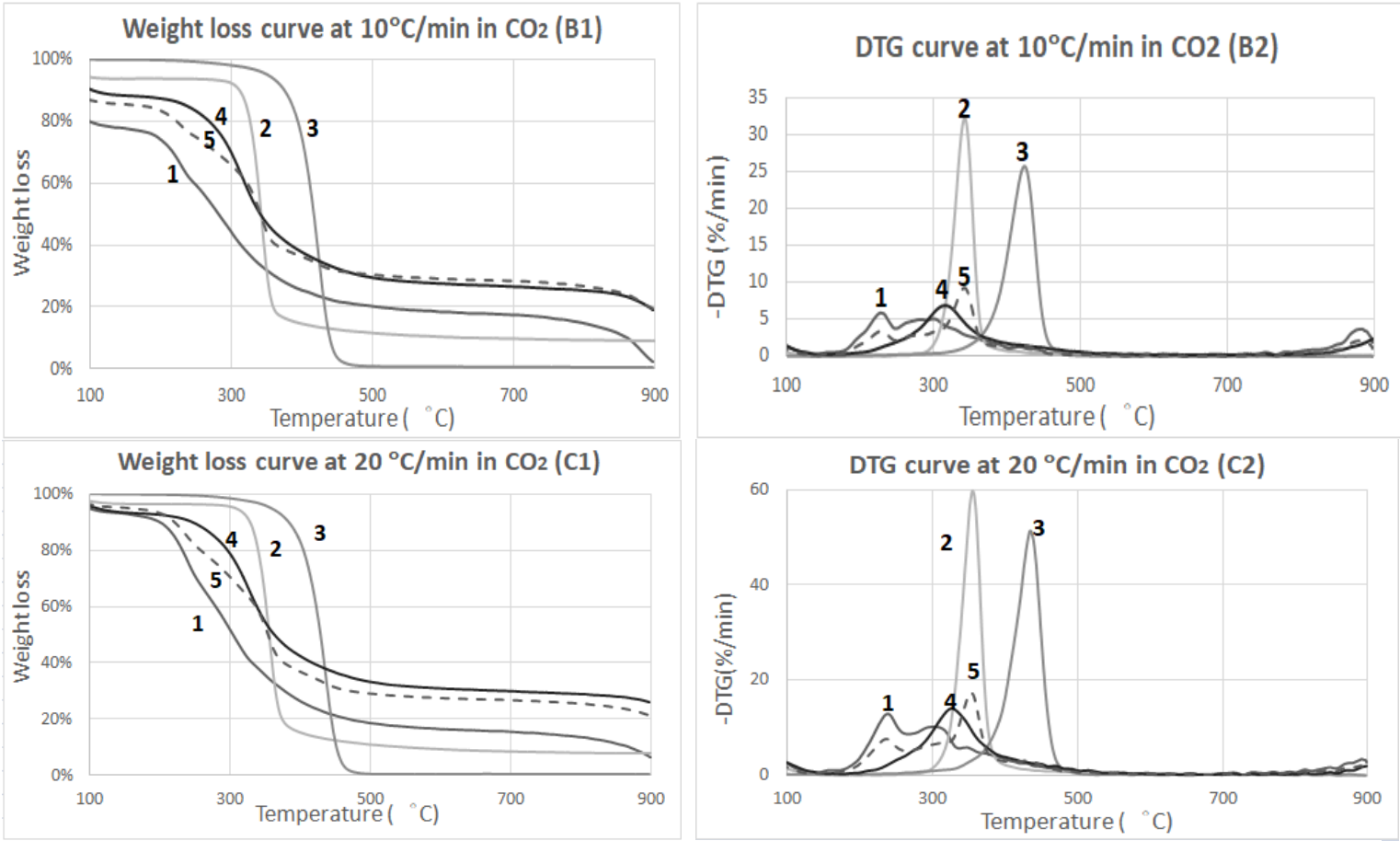

202
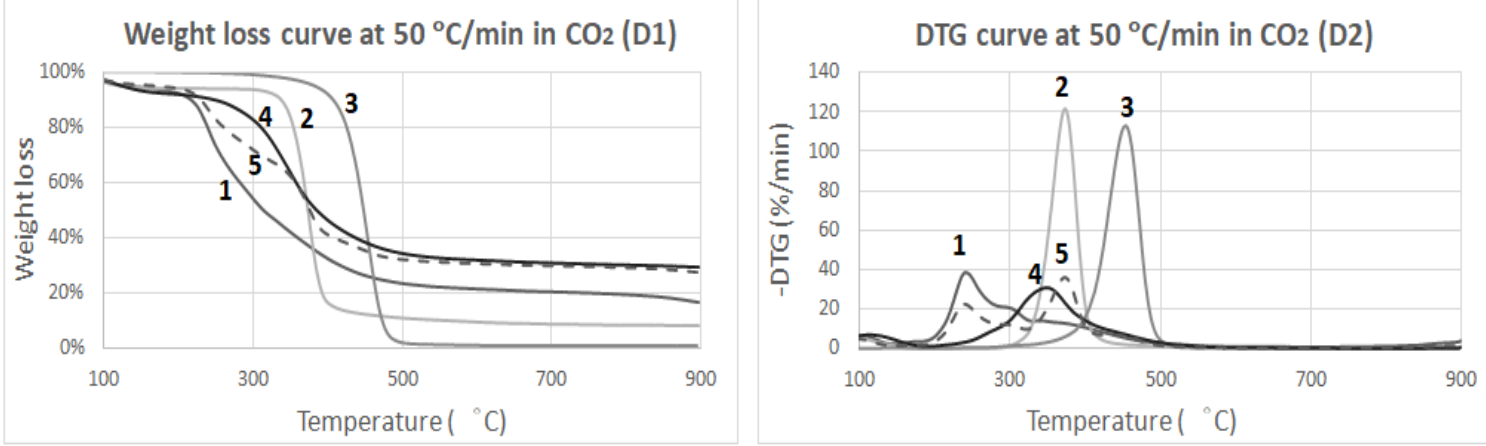

203

204

205

206

207

208

209

210

Figure 2, the TG curve of the model spirulina is relatively similar to that of the actual spirulina under both atmospheres. As for the DTG curves, the theoretical weight loss rate has two peak values, around 200 and $350^{\circ} \mathrm{C}$ under both atmospheres, which is similar to the DTG curve of the pyrolysis of ovalbumin. This is due to the excessive undefined substances contained in ovalbumin, rather than in spirulina. Therefore, the first peak in DTG curves of both spirulina and its model curve is attributed to those components that are not 
211 within the scope of the model compounds. The second peak appeared at higher pyrolysis

212 temperature with larger weight loss rate is likely associated with the thermal hysteresis.

213 The $\mathrm{CO}_{2}$ gasification of carbon normally occurs more significantly at high temperature range

214 above $800^{\circ} \mathrm{C}$ and leads to the significant consumption of carbonaceous residues [36].

215 Therefore, for comparison of the pyrolytic behavior under two different atmospheres, the

216 lower temperature range of the TGA curves $\left(100-800^{\circ} \mathrm{C}\right)$ is examined in this study. Error!

217 Reference source not found. summarizes the primary pyrolysis parameters including $\mathrm{Y}_{\text {char, }}$, the

218 weight percentage of char residue at $800^{\circ} \mathrm{C} ; \mathrm{T}_{\mathrm{i}}$, the initial temperature when volatile matters

219 start to release; $D_{m}$, the maximum weight loss rate; $T_{m}$, the peak temperature; $\Delta T_{1 / 2}$, the

220 half peak width temperature, which were all derived from TG and DTG curves (Figure 1 and

221
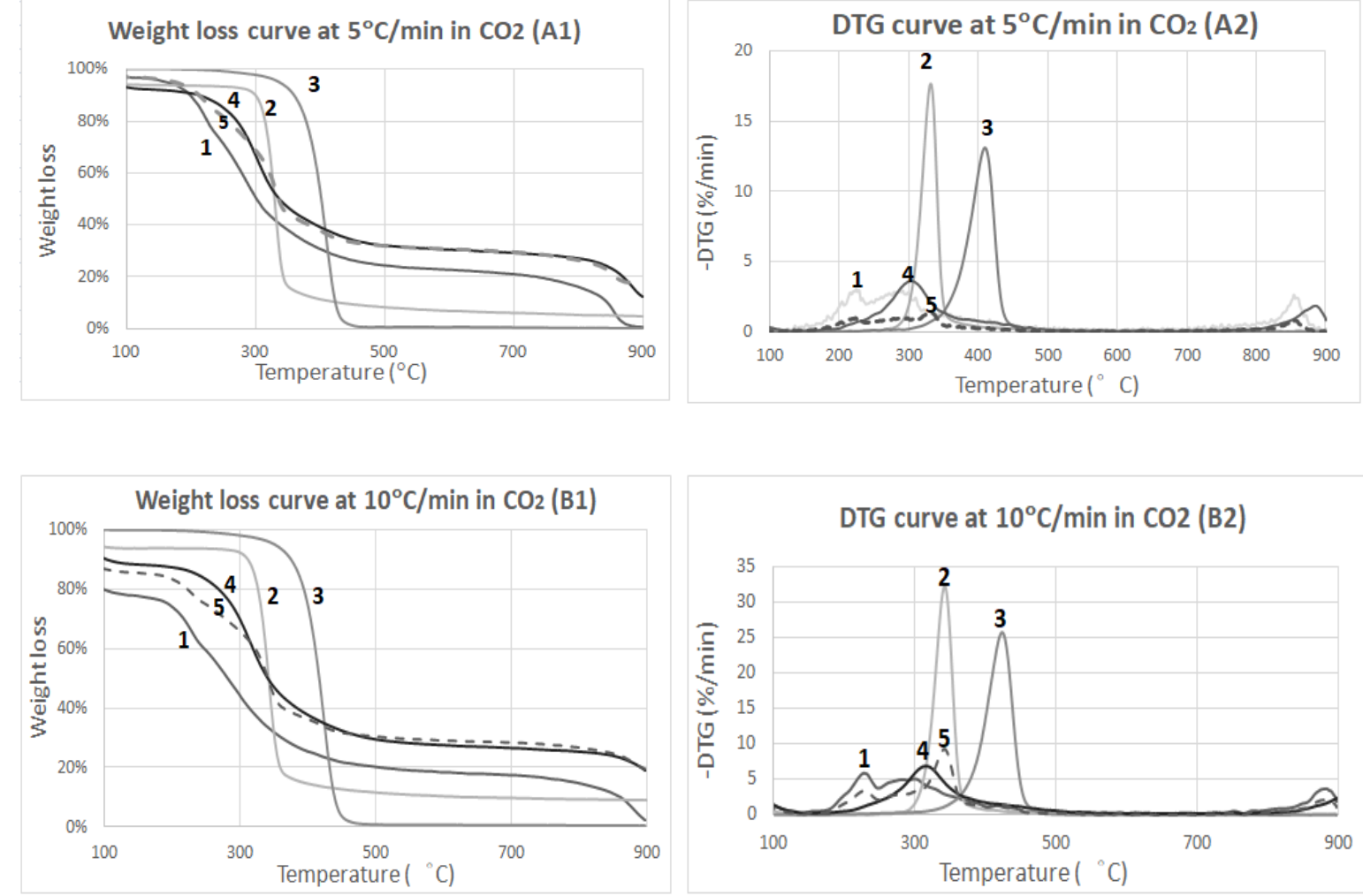

222 

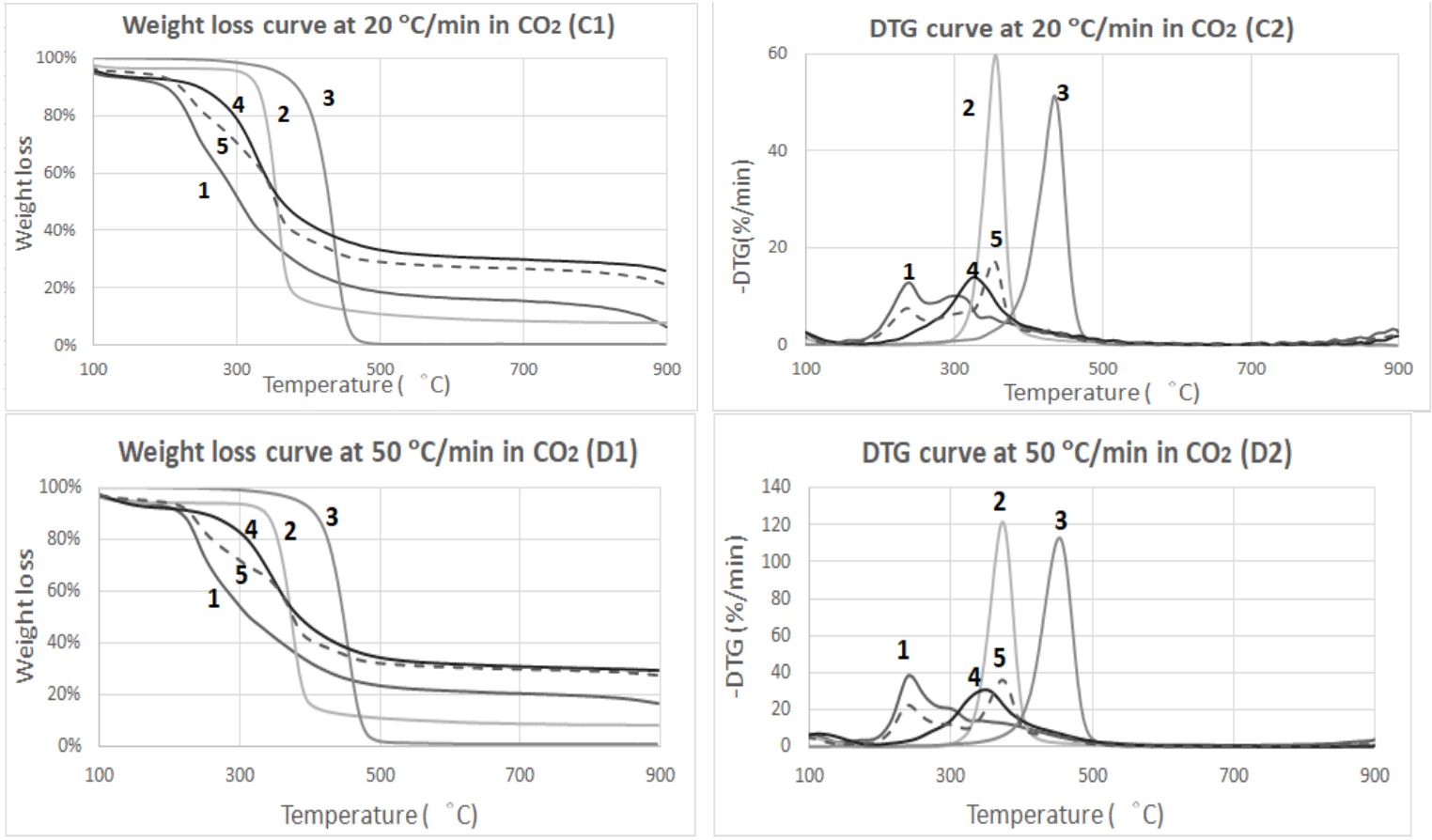

224

225

226

227

228

229

230

231

232

233

234

235

236

Figure 2). From Error! Reference source not found., the char residue of oil droplet, cellulose, ovalbumin and spirulina after pyrolysis remained relatively unchanged under both atmospheres for the different heating rates. Due to the thermal hysteresis, $D_{m}, T_{m}$ and $T_{i}$ increased with increasing heating rate as observed in both atmospheres. It has been previously reported that the higher heating rate could reduce the reaction time and postpone the pyrolysis [37]. Moreover, according to a typical comparison of TGA curves between $\mathrm{N}_{2}$ and $\mathrm{CO}_{2}$ atmospheres (Figure 3), $\mathrm{CO}_{2}$ assisted in the pyrolysis of ovalbumin and therefore the protein in algae, which shows a larger weight loss rate compared with that under $\mathrm{N}_{2}$. However, the weight loss curves of cellulose and oil droplet pyrolysis derived in $\mathrm{CO}_{2}$ stayed consistent with curves under $\mathrm{N}_{2}$. This refers to the findings that $\mathrm{CO}_{2}$ does not participate in the pyrolysis of carbohydrate and lipid contained in algae. 


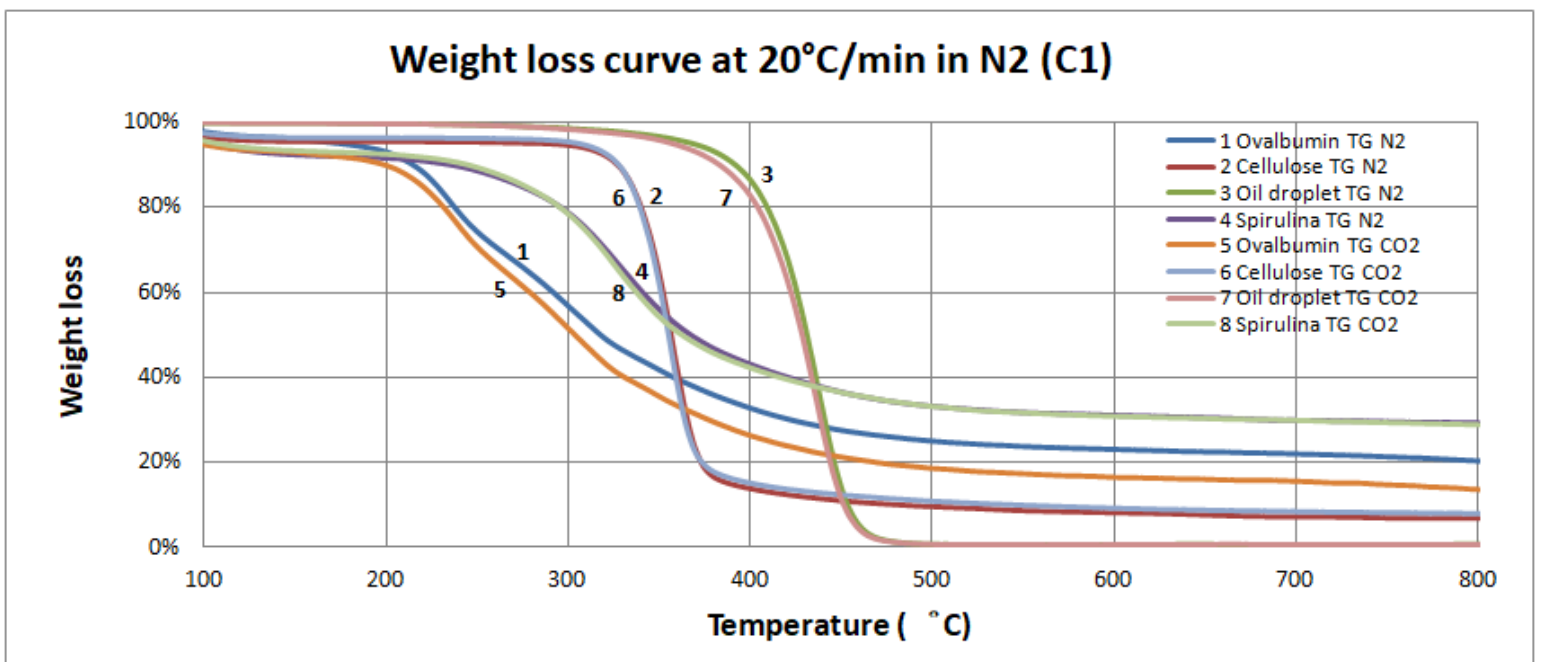

238 Figure 3 Weight loss curves of ovalbumin ( 1 and 5), cellulose ( 2 and6), oil droplet ( 3 and 239 7) and spirulina (4 and 8 ) at $20 \mathrm{~V}\left[\mathrm{C} / \mathrm{min}\right.$ under $\mathrm{N}_{2}$ and $\mathrm{CO}_{2}$. 
Table 2 Features of the pyrolysis of cellulose, ovalbumin, oil droplet and spirulina under $\mathbf{N}_{2}$ and $\mathrm{CO}_{2}$.

\begin{tabular}{|c|c|c|c|c|c|c|c|c|c|}
\hline \multirow{2}{*}{ Sample } & \multirow[b]{2}{*}{$\beta\left({ }^{\circ} \mathrm{C} \min ^{-1}\right)$} & \multicolumn{4}{|c|}{$\mathbf{N}_{2}$} & \multicolumn{4}{|c|}{$\mathrm{CO}_{2}$} \\
\hline & & 5 & 10 & 20 & 50 & 5 & 10 & 20 & 50 \\
\hline \multirow{5}{*}{ Ovalbumin } & $Y_{\text {char }}(\%)$ & 14.4 & 20.2 & 20.2 & 18.4 & 15.9 & 14.6 & 14.0 & 19.5 \\
\hline & $\mathrm{T}_{\mathrm{i}}\left({ }^{\circ} \mathrm{C}\right)$ & 186 & 193 & 197 & 208 & 187 & 197 & 202 & 214 \\
\hline & $\mathrm{T}_{\mathrm{m}}\left({ }^{\circ} \mathrm{C}\right)$ & 219 & 228 & 232 & 242 & 216 & 224 & 231 & 245 \\
\hline & $\mathrm{D}_{\mathrm{m}}(\% / \mathrm{min})$ & -2.3 & -4.7 & -9.7 & -23.9 & -2.3 & -4.4 & -9.0 & -25.1 \\
\hline & $\Delta \mathrm{T}_{1 / 2}\left({ }^{\circ} \mathrm{C}\right)$ & 78 & 92 & 123 & 137 & 87 & 93 & 98 & 140 \\
\hline \multirow{5}{*}{ Cellulose } & $Y_{\text {char }}(\%)$ & 12.1 & 8.6 & 6.6 & 8.8 & 5.4 & 9.3 & 8.1 & 8.7 \\
\hline & $\mathrm{T}_{\mathrm{i}}\left({ }^{\circ} \mathrm{C}\right)$ & 299 & 309 & 319 & 330 & 297 & 289 & 318 & 330 \\
\hline & $\mathrm{T}_{\mathrm{m}}\left({ }^{\circ} \mathrm{C}\right)$ & 326 & 338 & 349 & 364 & 325 & 338 & 350 & 364 \\
\hline & $\mathrm{D}_{\mathrm{m}}(\% / \mathrm{min})$ & -13.6 & -25.2 & -47.4 & -100.1 & -13.9 & -25.5 & -47.8 & -101.5 \\
\hline & $\Delta \mathrm{T}_{1 / 2}\left({ }^{\circ} \mathrm{C}\right)$ & 67 & 85 & 125 & 176 & 67 & 81 & 90 & 143 \\
\hline \multirow{5}{*}{ Oil droplet } & $Y_{\text {char }}(\%)$ & 0.5 & 0.5 & 0.7 & 0.7 & 0.4 & 0.6 & 0.7 & 0.9 \\
\hline & $\mathrm{T}_{\mathrm{i}}\left({ }^{\circ} \mathrm{C}\right)$ & 240 & 255 & 261 & 274 & 209 & 223 & 226 & 233 \\
\hline & $\mathrm{T}_{\mathrm{m}}\left({ }^{\circ} \mathrm{C}\right)$ & 410 & 422 & 437 & 455 & 410 & 423 & 435 & 449 \\
\hline & $\mathrm{D}_{\mathrm{m}}(\% / \mathrm{min})$ & -13.5 & -25.9 & -53.0 & -114.2 & -13.1 & -25.7 & -51.4 & -115.0 \\
\hline & $\Delta \mathrm{T}_{1 / 2}\left({ }^{\circ} \mathrm{C}\right)$ & 91 & 106 & 114 & 135 & 108 & 119 & 115 & 107 \\
\hline \multirow{5}{*}{ Spirulina } & $Y_{\text {char }}(\%)$ & 27.0 & 27.0 & 29.2 & 29.6 & 27.0 & 25.5 & 28.7 & 30.1 \\
\hline & $\mathrm{T}_{\mathrm{i}}\left({ }^{\circ} \mathrm{C}\right)$ & 225 & 235 & 243 & 255 & 227 & 236 & 243 & 254 \\
\hline & $\mathrm{T}_{\mathrm{m}}\left({ }^{\circ} \mathrm{C}\right)$ & 300 & 310 & 322 & 338 & 296 & 306 & 322 & 337 \\
\hline & $\mathrm{D}_{\mathrm{m}}(\% / \mathrm{min})$ & -2.9 & -5.8 & -11.5 & -27.6 & -2.8 & -5.8 & -10.9 & -24.8 \\
\hline & $\Delta \mathrm{T}_{1 / 2}\left({ }^{\circ} \mathrm{C}\right)$ & 125 & 146 & 169 & 192 & 131 & 143 & 178 & 194 \\
\hline
\end{tabular}




\subsection{Kinetic study}

\section{3.2.1 Determination of activation energy via Kissinger- Akahira-Sunose (KAS)}

246 Amongst the three stages of pyrolysis, the second stage-devolatilization is regarded as the

247 major step in algae decomposition, and thus the main scope of study. Based on the starting 248 and finishing temperatures, under both atmospheres, ovalbumin was the first to 249 decompose at around $180^{\circ} \mathrm{C}$ and sustained until $600^{\circ} \mathrm{C}$ at which the weight loss rate was 250 nearly zero. Cellulose was the second to pyrolyze at around $250-500^{\circ} \mathrm{C}$ and oil droplet was 251 the last to initiate its pyrolysis at $300^{\circ} \mathrm{C}$ and finishing at around $550^{\circ} \mathrm{C}$. As a result of the 252 synergistic effect of protein, carbohydrate and lipid in algae, the actual spirulina 253 decomposed within a smaller temperature range, but still within the decomposition range 254 of the three individual components, at around $220^{\circ} \mathrm{C}$ and terminating at $420^{\circ} \mathrm{C}$. Therefore, 255 after considering the pyrolysis of all four samples, temperature range for applying KAS 256 method was selected as 120 to $600^{\circ} \mathrm{C}$, which covered the temperatures of the whole 257 conversion process.

258 In order to study the dependence of activation energy of model compounds on the 259 increasing conversion rate $(\alpha), 19$ different conversion rates from $5 \%$ to $95 \%$ at $5 \%$ intervals 260 were investigated at four heating rates of $5,10,20$ and $50{ }^{\circ} \mathrm{C} / \mathrm{min}$ under $\mathrm{N}_{2}$ and $\mathrm{CO}_{2}$ based 261 on KAS method. The activation energy $\left(E_{a}\right)$ and correlation factor $\left(R^{2}\right)$ of model compounds 262 are listed in Error! Reference source not found.. Generally, due to the delay of heat transfer 263 from pan to sample, the thermal delay was inherited into the process as the evident from 264 the shift of DTG peak values towards higher temperature zone as the heating rate increased. 
265 The activation energy derived, via KAS method, during the main stage of pyrolysis is of 266 sufficient accuracy and can be deployed for analysis [38]. Moreover, the $\mathrm{R}^{2}$ values derived 267 for this stage are mostly above 0.90 , which indicates the reliability of the calculated $E_{a}$. 268 However, the initial and final stages of sample conversion might contain unavoidable errors 269 due to the compositional heterogeneity of solid sample and experimental errors [39, 40]. 270 Figure 4 shows the plot of activation energy obtained from KAS method against the 271 conversion rate under $\mathrm{N}_{2}$ and $\mathrm{CO}_{2}$ atmosphere for the pyrolysis of model compounds and 272 actual algae. 
274 Table 3 The activation energy $\left(E_{a}, \mathrm{~kJ} / \mathrm{mol}\right)$ and correlation factor $\left(R^{2}\right)$ of model compounds 275 and spirulina under $\mathrm{N}_{2}$ and $\mathrm{CO}_{2}$ at different conversion rate $(\alpha)$ using KAS method.

\begin{tabular}{|c|c|c|c|c|c|c|c|c|}
\hline \multicolumn{9}{|c|}{$\mathbf{N}_{2}$} \\
\hline & \multicolumn{2}{|c|}{ Ovalbumin } & \multicolumn{2}{|c|}{$\alpha$-Cellulose } & \multicolumn{2}{|c|}{ Oil droplet } & \multicolumn{2}{|c|}{ Spirulina } \\
\hline$\alpha$ & $E_{a}$ & $\mathrm{R}^{2}$ & $E_{a}$ & $\mathrm{R}^{2}$ & $E_{a}$ & $R^{2}$ & $E_{a}$ & $R^{2}$ \\
\hline $5 \%$ & 188.4 & 0.9880 & 202.5 & 0.9915 & 123.1 & 0.9323 & 162.5 & 0.9978 \\
\hline $10 \%$ & 202.4 & 0.9881 & 198.9 & 0.9963 & 136.1 & 0.9763 & 177.5 & 0.9987 \\
\hline $15 \%$ & 209.7 & 0.9892 & 196.2 & 0.9970 & 147.0 & 0.9905 & 183.2 & 0.9996 \\
\hline $20 \%$ & 209.9 & 0.9836 & 194.7 & 0.9972 & 154.9 & 0.9934 & 183.0 & 0.9998 \\
\hline $25 \%$ & 231.6 & 0.9920 & 193.6 & 0.9974 & 163.2 & 0.9965 & 182.2 & 0.9997 \\
\hline $30 \%$ & 232.0 & 0.9921 & 191.7 & 0.9977 & 166.0 & 0.9973 & 182.1 & 0.9998 \\
\hline $35 \%$ & 234.6 & 0.9808 & 189.9 & 0.9979 & 169.8 & 0.9979 & 182.0 & 0.9997 \\
\hline $40 \%$ & 237.9 & 0.9654 & 188.1 & 0.9982 & 173.0 & 0.9981 & 182.6 & 0.9995 \\
\hline $45 \%$ & 237.9 & 0.9675 & 186.8 & 0.9984 & 175.2 & 0.9987 & 183.9 & 0.9990 \\
\hline $50 \%$ & 233.4 & 0.9696 & 185.6 & 0.9984 & 186.1 & 0.9936 & 186.8 & 0.9985 \\
\hline $55 \%$ & 231.7 & 0.9658 & 184.5 & 0.9985 & 189.6 & 0.9920 & 191.2 & 0.9974 \\
\hline $60 \%$ & 240.8 & 0.9490 & 182.9 & 0.9987 & 183.0 & 0.9980 & 200.0 & 0.9956 \\
\hline $65 \%$ & 255.0 & 0.9195 & 181.0 & 0.9990 & 179.5 & 0.9988 & 218.0 & 0.9914 \\
\hline $70 \%$ & 278.5 & 0.8695 & 179.3 & 0.9990 & 180.9 & 0.9987 & 249.2 & 0.9842 \\
\hline $75 \%$ & 331.6 & 0.7119 & 178.2 & 0.9992 & 182.1 & 0.9985 & 299.5 & 0.9436 \\
\hline $80 \%$ & 165.2 & 0.1812 & 176.2 & 0.9992 & 183.6 & 0.9986 & 335.5 & 0.9228 \\
\hline $85 \%$ & -29.8 & 0.0157 & 174.1 & 0.9994 & 183.6 & 0.9985 & 305.7 & 0.8717 \\
\hline $90 \%$ & -64.7 & 0.3252 & 171.4 & 0.9994 & 185.3 & 0.9980 & 203.2 & 0.4713 \\
\hline $95 \%$ & 334.3 & 0.6023 & 167.7 & 0.7146 & 180.6 & 0.9972 & 28.8 & 0.0255 \\
\hline \multicolumn{9}{|c|}{$\mathrm{CO}_{2}$} \\
\hline & \multicolumn{2}{|c|}{ Ovalbumin } & \multicolumn{2}{|c|}{$\alpha$-Cellulose } & \multicolumn{2}{|c|}{ Oil droplet } & \multicolumn{2}{|c|}{ Spirulina } \\
\hline$\alpha$ & $E_{a}$ & $\mathrm{R}^{2}$ & $E_{a}$ & $\mathrm{R}^{2}$ & $E_{a}$ & $R^{2}$ & $E_{a}$ & $R^{2}$ \\
\hline $5 \%$ & 148.9 & 0.9820 & 187.6 & 0.9975 & 156.9 & 0.9918 & 178.1 & 0.9981 \\
\hline $10 \%$ & 183.8 & 0.9844 & 189.9 & 0.9777 & 168.6 & 0.9945 & 218.4 & 0.9976 \\
\hline $15 \%$ & 202.3 & 0.9838 & 187.1 & 0.9955 & 173.8 & 0.9957 & 233.2 & 0.9996 \\
\hline $20 \%$ & 231.5 & 0.9698 & 183.6 & 0.9980 & 181.1 & 0.9962 & 234.9 & 0.9978 \\
\hline $25 \%$ & 315.0 & 0.9291 & 180.6 & 0.9985 & 184.4 & 0.9959 & 235.2 & 0.9957 \\
\hline $30 \%$ & 376.4 & 0.8623 & 178.5 & 0.9988 & 188.5 & 0.9960 & 237.6 & 0.9924 \\
\hline $35 \%$ & 420.8 & 0.8267 & 177.6 & 0.9987 & 192.5 & 0.9962 & 243.6 & 0.9883 \\
\hline $40 \%$ & 462.5 & 0.7931 & 175.6 & 0.9988 & 193.4 & 0.9970 & 255.5 & 0.9776 \\
\hline $45 \%$ & 504.4 & 0.7552 & 174.7 & 0.9990 & 197.3 & 0.9967 & 278.2 & 0.9533 \\
\hline $50 \%$ & 572.0 & 0.6446 & 173.6 & 0.9990 & 198.6 & 0.9971 & 314.7 & 0.8680 \\
\hline $55 \%$ & 298.5 & 0.0759 & 172.5 & 0.9993 & 199.6 & 0.9975 & 316.7 & 0.5007 \\
\hline $60 \%$ & -485.6 & 0.5018 & 172.2 & 0.9994 & 202.2 & 0.9973 & -52.2 & 0.0139 \\
\hline $65 \%$ & -291.7 & 0.8597 & 172.0 & 0.9995 & 203.7 & 0.9975 & -182.0 & 0.4655 \\
\hline $70 \%$ & -168.0 & 0.9059 & 171.7 & 0.9997 & 204.2 & 0.9977 & -147.9 & 0.7375 \\
\hline $75 \%$ & -96.8 & 0.9426 & 170.9 & 0.9999 & 205.1 & 0.9978 & -97.0 & 0.8374 \\
\hline $80 \%$ & -47.0 & 0.9233 & 170.4 & 1.0000 & 206.0 & 0.9980 & -45.8 & 0.8669 \\
\hline $85 \%$ & -53.3 & 0.9153 & 171.5 & 1.0000 & 206.4 & 0.9981 & -43.8 & 0.9261 \\
\hline $90 \%$ & -88.1 & 0.7844 & 179.0 & 0.9998 & 208.0 & 0.9977 & -47.4 & 0.9196 \\
\hline $95 \%$ & -205.3 & 0.1403 & 342.8 & 0.2799 & 209.5 & 0.9984 & -75.2 & 0.8890 \\
\hline
\end{tabular}



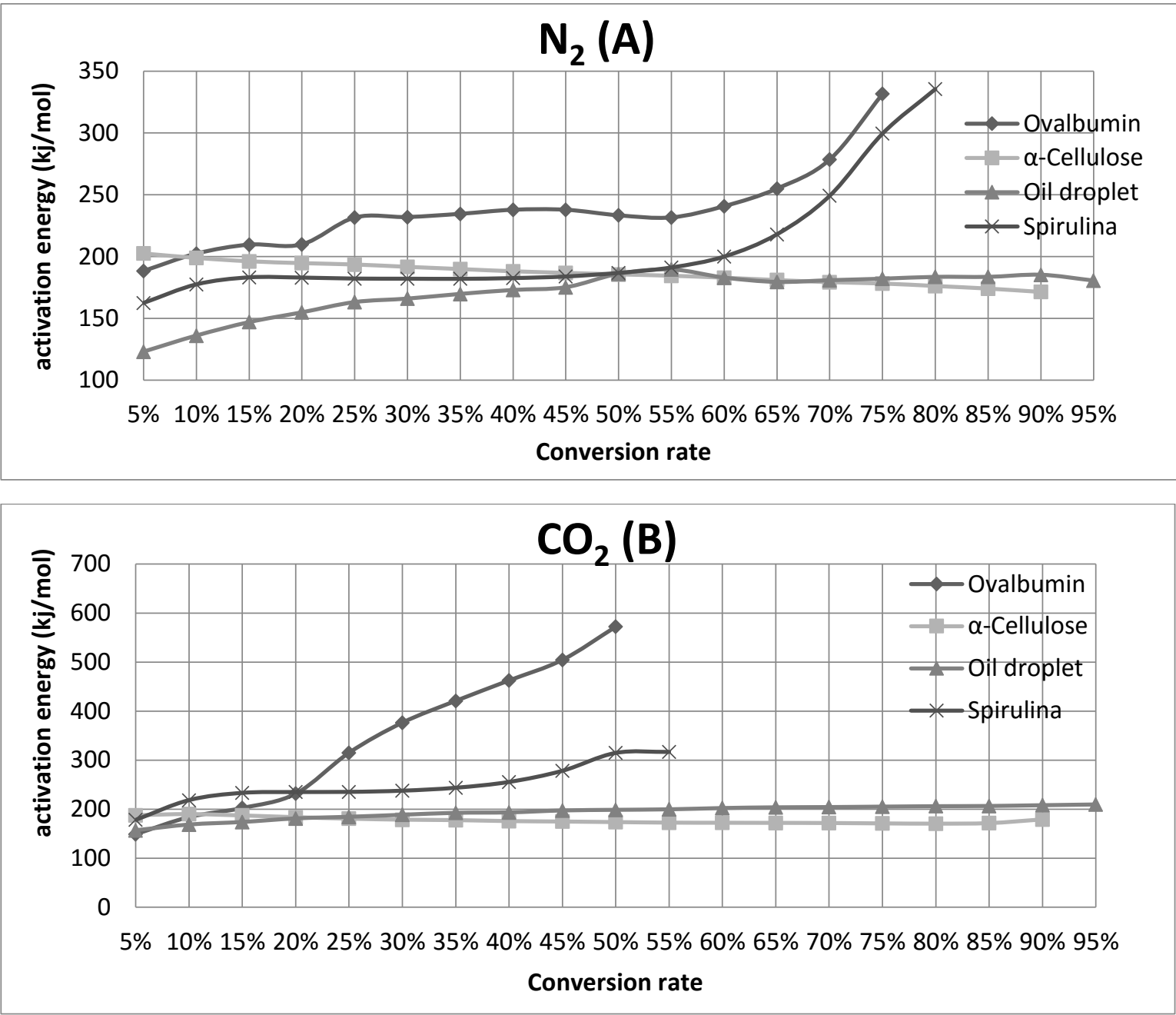

Figure 4 The activation energy of ovalbumin, cellulose, oil droplet and spirulina against the conversion rate under $\mathrm{N}_{2}(\mathrm{~A})$ and $\mathrm{CO}_{2}(B)$

282

283 It is noticed that $E_{a}$ of three model compounds varied along with the increment of conversion rate. The $E_{a}$ of oil droplet increased gradually from 123.1 to $175.2 \mathrm{~kJ} / \mathrm{mol}$ within the conversion range of 5 to $45 \%$, after which it remained relatively unchanged starting 286 from around $180 \mathrm{~kJ} / \mathrm{mol}$ in $\mathrm{N}_{2}$. Similarly, when $\mathrm{CO}_{2}$ was used, $\mathrm{E}_{\mathrm{a}}$ of oil droplet progressively increased from 156.9 to $197.3 \mathrm{~kJ} / \mathrm{mol}$ within the conversion rate of 5-45\%, while that value 
288 fluctuated at round $200 \mathrm{~kJ} / \mathrm{mol}$ from 50 to $95 \%$ conversion. The $E_{a}$ values were $5.3-27.5 \%$

289 larger than those derived in $\mathrm{N}_{2}$, which suggested that the lipid content in algae is relatively 290 more stable and difficult to decompose under $\mathrm{CO}_{2}$ atmosphere. The results agreed with the 291 initial test at the beginning of pyrolysis where oil droplet showed the highest activation 292 energy amongst the three model compounds, which was corresponding to the order of $T_{i}$ 293 values in TG analysis.

294 A contrary trend was found in the pyrolysis of cellulose under $N_{2}$ atmosphere, where the 295 activation energy reduced gradually from 202.5 to $171.4 \mathrm{~kJ} / \mathrm{mol}$ for the conversion of 5 to $29690 \%$. As for the pyrolysis of cellulose in $\mathrm{CO}_{2}$, the activation energy also decreased from 187.6 297 to $171.5 \mathrm{~kJ} / \mathrm{mol}$ for the same conversion range. According to Figure 4, a slightly lower 298 activation energy was recorded for the decomposition of cellulose under $\mathrm{CO}_{2}$, in 299 comparison with the energy calculated using $N_{2}$ as the carrier gas. This is in opposite to that 300 found in lipid pyrolysis.

301 As for the ovalbumin, the activation energy increased from 188.4 to $209.9 \mathrm{~kJ} / \mathrm{mol}$ when the 302 conversion $(\alpha)$ increased from 5 to $20 \%$. It increased slightly to $230 \mathrm{~kJ} / \mathrm{mol}$ when the 303 conversion further increased to $55 \%$ and peaked at $331.6 \mathrm{~kJ} / \mathrm{mol}$ when conversion was $75 \%$.

$304 E_{a}$ values could be ignored beyond the conversion rate of $80 \%$, which mainly caused by the 305 crossover of TG weight loss curve resulted from the heterogeneous nature in composition 306 of solid sample [41]. However, the activation energy distribution indicated a different 307 pattern in $\mathrm{CO}_{2}$. The energy required increased significantly from 148.9 to $572 \mathrm{~kJ} / \mathrm{mol}$ for the 308 conversion range of $5 \%$ to $50 \%$. After that, the activation energy declined to lower than zero. 
309 The exhaustion of ovalbumin occurred after the conversion rate of $55 \%$. This indicates that

310 the pyrolysis of ovalbumin under $\mathrm{CO}_{2}$ is more feasible at conversion rate lower than $30 \%$,

311 and the whole process is more efficient compared with $\mathrm{N}_{2}$ as carrier gas.

312 For spirulina pyrolysis under $\mathrm{N}_{2}$, the activation energy increased from 160 to $180 \mathrm{~kJ} / \mathrm{mol}$ (5\%

$313<\alpha<15 \%)$ and increased steadily to $190 \mathrm{~kJ} / \mathrm{mol}(20 \%<\alpha<50 \%)$, after which the value

314 surged to $335 \mathrm{~kJ} / \mathrm{mol}(55 \%<\alpha<80 \%)$. Similar to the pyrolysis of ovalbumin, the activation

315 energy then decreased dramatically to nearly zero. Since a large proportion of spirulina

316 consists of protein with content of $57.8 \mathrm{wt}$. \%, the activation energy for the pyrolysis of this

317 algae followed a similar trend as shown in ovalbumin under $\mathrm{CO}_{2}$. This was clear from the

318 increase in $E_{a}$ during the initial stage from 178 to $317 \mathrm{~kJ} / \mathrm{mol}(5 \%<\alpha<55 \%)$. It is also

319 obvious that the pyrolysis in $\mathrm{CO}_{2}$ required higher activation energy compared to $\mathrm{N}_{2}$ as carrier

320 gas but the pyrolysis in $\mathrm{CO}_{2}$ proceeded quicker and ended earlier.

321 Overall, by comparing activation energy derived from the pyrolysis of three model

322 compounds under $\mathrm{N}_{2}$ and $\mathrm{CO}_{2}$, the ovalbumin required lower amount of energy to

323 decompose and the process proceeded quicker under $\mathrm{CO}_{2}$ atmosphere. It was found in this

324 study that $\mathrm{CO}_{2}$ could assist in the pyrolysis of algal protein. Proteins are long chains of

325 polymerized amino acids, also involved in cell structure. There are various species of protein

326 contained in algae, since one single cell produces thousands of different proteins with

327 different amino acid composition. The nitrogen-released compounds are mainly in the form

328 of organic nitrites, nitriles, amines, amides, indoles, pyrroles and their derivatives [42]. 
329 However, under $\mathrm{CO}_{2}$ atmosphere, the activation energy remained relatively unchanged for

330 the pyrolysis of cellulose, while higher activation energy of oil droplet highlighted the 331 difficulty for algal lipid to decompose.

\section{$332 \quad$ 3.2.2 Determination of reaction model via Coats- Redfern method}

333 According to TG/DTG analysis, heating rate affected the pyrolysis process significantly. Due

334 to the severe thermal lag, the kinetic factors calculated based on high heating rates were 335 usually underestimated values as compared to the actual values $[43,44]$. The total time for 336 pyrolysis would be reduced by the rising heating rate, so is the period of heat transfer from 337 pan to the sample; thus, the temperature of decomposition will be drifted to higher 338 temperatures. Hence, to minimize the influence of thermal hysteresis, result collected 339 under low pyrolysis heating rate of $5^{\circ} \mathrm{C} / \mathrm{min}$ was used to determine the reaction model. 340 Similar approach was carried out in other open literatures $[8,10]$. Commonly-used

341 mechanism models were substituted into Coats-Redfern method to plot $\ln \frac{G(\alpha)}{T^{2}}$ against

$342-\frac{1}{R T}$ for the major pyrolysis stage. As the temperature increasing, the degradation of 343 samples could be devided into two ranges (Events I and II) under different reaction 344 mechanisms. On the basis of $\mathrm{R}^{2}$ fitting method, the category of mechanism, activation 345 energy $\left(E_{a}\right)$, and pre-exponential $(A)$ corresponding to the best regression value, among the 346 application of each form, $G(\alpha)$, as shown in Error! Reference source not found.. 
Table 4 Activation energy, pre-exponential factor and related kinetic models of Events I and II under $\mathbf{N}_{2}$ and $\mathrm{CO}_{2}$.

\begin{tabular}{|c|c|c|c|c|c|c|c|c|c|}
\hline & & \multicolumn{4}{|c|}{$\mathbf{N}_{2}$} & \multicolumn{4}{|c|}{$\mathrm{CO}_{2}$} \\
\hline & Parameters & Ovalbumin & Cellulose & $\begin{array}{c}\text { Oil } \\
\text { droplet }\end{array}$ & Spirulina & Ovalbumin & Cellulose & $\begin{array}{c}\text { Oil } \\
\text { droplet }\end{array}$ & Spirulina \\
\hline \multirow{4}{*}{$\begin{array}{c}\text { Event } \\
\text { I }\end{array}$} & Range $\left({ }^{\circ} \mathrm{C}\right)$ & $180-220$ & $300-325$ & $340-440$ & $220-270$ & $180-220$ & $300-325$ & $340-430$ & $220-300$ \\
\hline & $E_{a}(\mathrm{~kJ} / \mathrm{mol})$ & 74.4 & 273.0 & 227.8 & 121.7 & 66.8 & 266.6 & 266.5 & 20.7 \\
\hline & Mechanism & $\begin{array}{l}\text { Second- } \\
\text { order } \\
\text { reaction } \\
\text { (F2) }\end{array}$ & $\begin{array}{l}\text { First- } \\
\text { order } \\
\text { reaction } \\
(F 1)\end{array}$ & $\begin{array}{c}\text { 1-D } \\
\text { diffusion } \\
\text { (D1) }\end{array}$ & $\begin{array}{c}\text { 1-D } \\
\text { diffusion } \\
\text { (D1) }\end{array}$ & $\begin{array}{l}\text { Second- } \\
\text { order } \\
\text { reaction } \\
\text { (F2) }\end{array}$ & $\begin{array}{l}\text { First-order } \\
\text { reaction } \\
\text { (F1) }\end{array}$ & $\begin{array}{c}\text { 2-D } \\
\text { diffusion } \\
\text { (D2) }\end{array}$ & $\begin{array}{c}\text { 1-D } \\
\text { diffusion } \\
\text { (D1) }\end{array}$ \\
\hline & $A\left(s^{-1}\right)$ & $3.3 \times 10^{6}$ & 23.4 & $1.4 \times 10^{16}$ & $4.6 \times 10^{4}$ & $4.0 \times 10^{5}$ & 22.8 & $\begin{array}{c}2.29 \times \\
10^{19}\end{array}$ & 0.3 \\
\hline \multirow{4}{*}{$\begin{array}{c}\text { Event } \\
\text { II }\end{array}$} & Range $\left({ }^{\circ} \mathrm{C}\right)$ & $220-400$ & $325-350$ & & $270-380$ & $220-400$ & $325-350$ & & $300-360$ \\
\hline & $E_{a}(\mathrm{~kJ} / \mathrm{mol})$ & 41.5 & 377.4 & & 53.0 & 24.4 & 344.2 & & 62.1 \\
\hline & Mechanism & $\begin{array}{l}\text { Second- } \\
\text { order } \\
\text { reaction } \\
\text { (F2) }\end{array}$ & $\begin{array}{l}\text { Second- } \\
\text { order } \\
\text { reaction } \\
(F 2)\end{array}$ & & $\begin{array}{l}\text { Second- } \\
\text { order } \\
\text { reaction } \\
\text { (F2) }\end{array}$ & $\begin{array}{l}\text { Second- } \\
\text { order } \\
\text { reaction } \\
\text { (F2) }\end{array}$ & $\begin{array}{l}\text { Second- } \\
\text { order } \\
\text { reaction } \\
\text { (F2) }\end{array}$ & & $\begin{array}{l}\text { Second- } \\
\text { order } \\
\text { reaction } \\
\text { (F2) }\end{array}$ \\
\hline & $A\left(s^{-1}\right)$ & 164.7 & 32.8 & & $4.3 \times 10^{9}$ & 0.6 & 29.9 & & 4.5 \\
\hline
\end{tabular}


According to Figure 4, the activation energy of ovalbumin would increase gradually during the initial decomposition stage and rocketed to high values in the end, which indicated that

351 the two-reaction mechanism dominated this stage of pyrolysis. The carbonaceous matters 352 of ovalbumin were the first to decompose from $180^{\circ} \mathrm{C}$, which fitted well with the Second353 order chemical reaction (F2) model, and required the lowest activation energy of 74.4 $354 \mathrm{~kJ} / \mathrm{mol}$. As the pyrolysis temperature increased, the activation energy of ovalbumin in Event 355 II reduced to $41.5 \mathrm{~kJ} / \mathrm{mol}$ from $220^{\circ} \mathrm{C}$, which was much lower than the value derived by KAS 356 method, and the mechanism of ovalbumin pyrolysis remained as F2 model. Cellulose was 357 the second model compound to decompose from 300 to $360^{\circ} \mathrm{C}$, which required higher 358 activation energy of the First-order chemical reaction (F1) model $(273.0 \mathrm{~kJ} / \mathrm{mol})$ in the 359 temperature range of $300-325^{\circ} \mathrm{C}$, followed by Event II. From 325 to $350^{\circ} \mathrm{C}$, the $\mathrm{E}_{\mathrm{a}}$ increased 360 to $377.4 \mathrm{~kJ} / \mathrm{mol}$ in F2 model. Compared to the results concluded from the KAS method, the 361 activation energy is very different. The $E_{a}$ decreased from 202.5 to $171.4 \mathrm{~kJ} / \mathrm{mol}$ during the 362 whole period of pyrolysis and increased to about $198.4 \mathrm{~kJ} / \mathrm{mol}$ at $\alpha=0.95$. Similarly, oil 363 droplet did not alter evidently and therefore, one reaction model was used in the pyrolysis 364 process, which appeared to be 1-D diffusion (D1) model. It was the last model substance to 365 decompose at $340{ }^{\circ} \mathrm{C}$ until $440{ }^{\circ} \mathrm{C}$ with activation energy of $227.8 \mathrm{~kJ} / \mathrm{mol}$, which was higher 366 than the value obtained via KAS method (approximately $180 \mathrm{~kJ} / \mathrm{mol}$ ). Hence, the protein in 367 algae was the first primary component to decompose during the second stage, followed by 368 carbohydrate which has higher activation energy whilst protein continued to generate 369 volatiles. Lipid in algae was the last component to pyrolyze, which required higher activation 370 energy and decomposed with the remaining carbohydrate and protein, simultaneously. 
371 However, the decomposition of spirulina was found to be in D1 model with an activation

372 energy of $122.6 \mathrm{~kJ} / \mathrm{mol}$ from 220 to $270^{\circ} \mathrm{C}$. After $270^{\circ} \mathrm{C}$, the mechanism was changed to $\mathrm{F} 2$

373 model and the $E_{a}$ required was reduced to an amount of $53.0 \mathrm{~kJ} / \mathrm{mol}$.

374 As for the $\mathrm{CO}_{2}$ atmosphere, ovalbumin was the first sample to decompose in $\mathrm{F} 2$ mechanism

375 which is the same as the decomposition under $\mathrm{N}_{2}$ with only $66.8 \mathrm{~kJ} / \mathrm{mol}$ activation energy

376 from $180^{\circ} \mathrm{C}$. After $220^{\circ} \mathrm{C}$. The activation energy then followed the same decreasing trend in

$377 \mathrm{~F} 2$ model to $24.4 \mathrm{~kJ} / \mathrm{mol}$ as $\mathrm{N}_{2}$ atmosphere. Meanwhile, compared with $\mathrm{N}_{2}$ atmosphere,

378 cellulose started to decompose in $\mathrm{F} 1$ model from 300 to $325^{\circ} \mathrm{C}$ with similar activation energy

$379(266.6 \mathrm{~kJ} / \mathrm{mol})$ and pre-exponential factor (22.8). The $E_{a}$ further increased to $344.2 \mathrm{~kJ} / \mathrm{mol}$

380 in the temperature range of 325 to $350^{\circ} \mathrm{C}$ in $\mathrm{F} 2$ model, which is comparable to the

381 parameters derived under $\mathrm{N}_{2}$. On the other hand, the oil droplet decomposed with higher

382 activation energy of $266.5 \mathrm{~kJ} / \mathrm{mol}$, compared to the value under $\mathrm{N}_{2}$ atmosphere. Therefore,

383 it is evident that similar decomposition sequence of the three model compounds can be

384 observed under $\mathrm{CO}_{2}$, compared to $\mathrm{N}_{2}$ as carrier gas. Moreover, activation energy for the

385 decomposition of the ovalbumin is smaller, which suggests that ovalbumin is easier to

386 decompose in $\mathrm{CO}_{2}$ atmosphere. As for the lipid, its decomposition occurred at higher

387 temperature with lower degradation rate and higher activation energy, which suggests that

388 it is difficult to decompose in $\mathrm{CO}_{2}$ atmosphere. This leads to the same conclusion as using

389 KAS method. Spirulina required less energy to proceed the decomposition under $\mathrm{CO}_{2}$, which

390 decomposed in D1 model with $20.7 \mathrm{~kJ} / \mathrm{mol}$ for Event I, and switched to F2 mechanism with

$391 \mathrm{E}_{\mathrm{a}}$ of $36.4 \mathrm{~kJ} / \mathrm{mol}$, compared to the decomposition under $\mathrm{N}_{2}$ atmosphere. 
392 The Coats-Redfern method, which is commonly applied in the determination of reaction 393 mechanism of biomass pyrolysis [45], requires the use of only one set of TG data, while iso394 conversional method (KAS) needs at least three sets of data to calculate the thermal 395 parameters. However, different methods are not exclusive, but mutually complementary in 396 the analysis of reaction mechanism [46].

\section{$397 \quad 3.3 \quad$ Characteristics of char}

398 Error! Reference source not found. summarizes the composition of char remaining after 399 pyrolysis under $\mathrm{N}_{2}$ and $\mathrm{CO}_{2}$ in four different heating rates. As there was minimal char left in 400 the crucibles after pyrolysis of oil droplet (<1wt. \%), hence, there are no results for char of 401 algal pseudo- lipid. The compositions of ovalbumin char changed significantly after pyrolysis 402 under $\mathrm{N}_{2}$ when four different heating rates were used. Carbon and oxygen content of the 403 char fluctuated around 25 and 70 wt. \%, respectively. But after pyrolysis in $\mathrm{CO}_{2}$, the carbon 404 content increased with the increasing of heating rate which then became similar at higher 405 heating rates of 20 and $50{ }^{\circ} \mathrm{C} / \mathrm{min}(14.9$ to $22.2 \mathrm{wt} . \%)$. This was also observed for the oxygen 406 content (55.9 to $67.6 \mathrm{wt}$ \%). It is apparent that using $\mathrm{CO}_{2}$ as carrier gas could reduce the 407 carbon and oxygen content in ovalbumin char residue as well as the overall char amount. 408 This reconfirms the previous findings where a smaller activation energy is required for the 409 pyrolysis of ovalbumin in $\mathrm{CO}_{2}$ as reported in Section 3.2.1. Due to the longer processing time 410 required for lower heating rates $\left(170 \mathrm{mins}\right.$ for $5^{\circ} \mathrm{C} / \mathrm{min}, 85 \mathrm{mins}$ for $10^{\circ} \mathrm{C} / \mathrm{min}, 42.5 \mathrm{mins}$ 411 for $20^{\circ} \mathrm{C} / \mathrm{min}$ and $17 \mathrm{mins}$ for $50^{\circ} \mathrm{C} / \mathrm{min}$ ), sample had sufficient time to contact and react 412 with $\mathrm{CO}_{2}$ via $\mathrm{C}+\mathrm{CO}_{2} \rightarrow 2 \mathrm{CO}$ reaction. This reduced the carbon content in char significantly, 
413 while increasing the compositions of other elements. Elements including $\mathrm{Na}, \mathrm{Mg}, \mathrm{Si}, \mathrm{P}, \mathrm{K}$,

414 and $\mathrm{Ca}$, in the char of ovalbumin pyrolyzed under $\mathrm{CO}_{2}$ increased steadily as the heating rate

415 was reduced. At the heating rate of $5^{\circ} \mathrm{C} / \mathrm{min}$, these elements were significantly larger than

416 the amount derived under $\mathrm{N}_{2}$, especially for $\mathrm{P}, \mathrm{K}, \mathrm{Ca}$, and $\mathrm{Mg}$ at 8.0, 10.3, 1.6 and 2.1 wt. \%,

417 respectively.

Table 5 Elemental compositions of solid residues of ovalbumin, cellulose and spirulina 419 derived by EDS.

\begin{tabular}{|c|c|c|c|c|c|c|c|c|c|c|c|c|}
\hline \multicolumn{13}{|c|}{ Ovalbumin } \\
\hline \multirow{2}{*}{$\begin{array}{l}\text { Heating } \\
\text { rate } \\
\left({ }^{\circ} \mathrm{C} / \mathrm{min}\right)\end{array}$} & \multicolumn{4}{|c|}{$\mathrm{N}_{2}$} & \multicolumn{4}{|c|}{$\mathrm{CO}_{2}$} & \multicolumn{4}{|c|}{ Char $\left(\mathrm{CO}_{2}\right)$} \\
\hline & 5 & 10 & 20 & 50 & 5 & 10 & 20 & 50 & 5 & 10 & 20 & 50 \\
\hline$C$ & 25.4 & 25.6 & 25.6 & 25.5 & 14.9 & 20.0 & 22.2 & 22.2 & 15.1 & 28.6 & 29.6 & 29.0 \\
\hline $\mathrm{N}$ & - & - & 0.4 & 0.3 & - & 0.9 & 0.9 & 1.7 & - & - & - & - \\
\hline $\mathrm{Na}$ & - & - & - & - & 0.3 & - & - & - & 9.5 & 7.2 & 5.7 & 5.3 \\
\hline $\mathrm{Mg}$ & 0.4 & 0.4 & 0.4 & 0.3 & 2.1 & 0.9 & 0.5 & 0.4 & 6.3 & 6.8 & 4.4 & 4.5 \\
\hline $\mathrm{Si}$ & - & - & - & - & 0.1 & - & - & - & - & 0.1 & 0.1 & - \\
\hline$P$ & 1.4 & 1.2 & 1.2 & 1.0 & 8.0 & 2.8 & 2.2 & 1.5 & 13.2 & 11.9 & 9.6 & 11.6 \\
\hline$S$ & - & - & - & 0.1 & - & - & - & - & - & - & - & - \\
\hline $\mathrm{Cl}$ & - & - & - & - & - & 0.1 & - & - & - & - & - & - \\
\hline K & 2.2 & 2.1 & 1.8 & 1.4 & 10.3 & 4.5 & 3.6 & 1.8 & 0.3 & 0.4 & 0.4 & 0.6 \\
\hline $\mathrm{Ca}$ & 0.4 & 0.2 & 0.2 & 0.2 & 1.6 & 0.4 & 0.7 & 0.2 & 11.6 & 11.9 & 12.9 & 16.5 \\
\hline $\mathrm{Fe}$ & - & - & - & 0.1 & - & - & - & - & 0.2 & 0.6 & 0.2 & 0.3 \\
\hline 0 & 70.3 & 70.5 & 70.6 & 70.8 & 55.9 & 62.9 & 66.4 & 67.6 & 43.0 & 31.8 & 36.6 & 31.6 \\
\hline \multicolumn{13}{|c|}{ Cellulose } \\
\hline Heating & \multicolumn{4}{|c|}{$\mathrm{N}_{2}$} & \multicolumn{4}{|c|}{$\mathrm{CO}_{2}$} & \multicolumn{4}{|c|}{ Char $\left(\mathrm{CO}_{2}\right)$} \\
\hline $\begin{array}{c}\text { rate } \\
\left({ }^{\circ} \mathrm{C} / \mathrm{min}\right)\end{array}$ & 5 & 10 & 20 & 50 & 5 & 10 & 20 & 50 & 5 & 10 & 20 & 50 \\
\hline C & 27.3 & 27.3 & 27.3 & 27.3 & 27.3 & 27.3 & 27.3 & 27.3 & 92.9 & 90.5 & 94.3 & 94.0 \\
\hline 0 & 72.7 & 72.7 & 72.7 & 72.7 & 72.7 & 72.7 & 72.7 & 72.7 & 7.1 & 9.5 & 5.7 & 6.0 \\
\hline \multicolumn{13}{|c|}{ Spirulina } \\
\hline Heating & \multicolumn{4}{|c|}{$\mathrm{N}_{2}$} & \multicolumn{4}{|c|}{$\mathrm{CO}_{2}$} & \multicolumn{4}{|c|}{ Char $\left(\mathrm{CO}_{2}\right)$} \\
\hline $\begin{array}{c}\text { rate } \\
\left({ }^{\circ} \mathrm{C} / \mathrm{min}\right)\end{array}$ & 5 & 10 & 20 & 50 & 5 & 10 & 20 & 50 & 5 & 10 & 20 & 50 \\
\hline$C$ & 25.4 & 23.1 & 24.1 & 25.0 & 3.7 & 15.2 & 23.8 & 24.5 & 2.0 & 7.7 & 9.2 & 9.1 \\
\hline $\mathrm{N}$ & - & - & 0.7 & 0.8 & - & - & - & - & - & - & - & - \\
\hline $\mathrm{Na}$ & 0.4 & 0.5 & 0.6 & 0.4 & 2.5 & 1.7 & 0.8 & 0.7 & 4.7 & 2.6 & 4.3 & 2.9 \\
\hline $\mathrm{Mg}$ & 0.5 & 0.8 & 0.6 & 0.4 & 4.5 & 2.3 & 0.8 & 0.7 & 5.9 & 6.8 & 4.8 & 4.9 \\
\hline $\mathrm{Al}$ & 0.1 & 0.3 & 0.3 & 0.2 & 3.0 & 0.9 & 0.6 & 0.1 & 2.2 & 1.8 & 2.9 & 3.1 \\
\hline $\mathrm{Si}$ & 0.4 & 0.4 & 0.2 & 0.2 & 2.8 & 1.0 & 0.9 & 0.3 & 5.2 & 2.5 & 5.4 & 4.1 \\
\hline
\end{tabular}




\begin{tabular}{|c|c|c|c|c|c|c|c|c|c|c|c|c|}
\hline $\mathrm{P}$ & 1.4 & 2.5 & 1.2 & 0.9 & 14.9 & 5.9 & 1.8 & 1.3 & 13.1 & 12.1 & 11.2 & 11.6 \\
\hline $\mathrm{S}$ & 0.1 & 0.1 & - & - & - & 0.1 & 0.1 & - & - & 0.1 & - & - \\
\hline $\mathrm{Cl}$ & - & - & - & - & - & 0.1 & - & - & 0.1 & - & - & - \\
\hline $\mathrm{K}$ & 0.9 & 1.5 & 1.0 & 0.8 & 13.7 & 7.0 & 1.8 & 1.6 & 9.4 & 9.7 & 7.7 & 10.3 \\
\hline $\mathrm{Ca}$ & 0.3 & 2.1 & 0.7 & 0.2 & 3.4 & 2.0 & 0.8 & 0.4 & 5.2 & 10.4 & 4.2 & 6.7 \\
\hline $\mathrm{Fe}$ & 0.1 & 1.0 & 0.3 & 0.4 & 3.6 & 1.8 & 1.1 & 0.4 & 4.2 & 5.6 & 3.0 & 4.3 \\
\hline $\mathrm{O}$ & 70.8 & 67.8 & 70.2 & 70.9 & 45.2 & 56.3 & 68.0 & 69.8 & 47.7 & 34.4 & 47.3 & 42.8 \\
\hline
\end{tabular}

As for the cellulose, the elements in char remained relatively the same for both $\mathrm{N}_{2}$ and $\mathrm{CO}_{2}$

422 atmospheres even in various heating rates (carbon, $27.3 \mathrm{wt}$ \%; oxygen, $72.7 \mathrm{wt} . \%$ ). This also

423 corresponded to the relatively unchanged activation energy calculated in Section 3.2.1. This

424 also indicated that $\mathrm{CO}_{2}$ minimally participated in the pyrolysis of carbohydrate contained in

425 algae.

426 Similar to the composition of ovalbumin char, $\mathrm{C}$ and $\mathrm{O}$ content of spirulina char under four

427 heating rates varied around 25 and 70 wt.\% in $\mathrm{N}_{2}$. However, char derived in $\mathrm{CO}_{2}$ contained

428 increased amount of carbon and oxygen as the heating rates became larger from 5 to

$42950^{\circ} \mathrm{C} / \mathrm{min}\left(3.7\right.$ to $24.5 \mathrm{wt} . \%$ and 45.2 to $69.8 \mathrm{wt} . \%$ respectively). At heating rate of $5^{\circ} \mathrm{C} / \mathrm{min}$,

430 elements of char obtained in $\mathrm{CO}_{2}$, including $\mathrm{P}, \mathrm{K}, \mathrm{Na}, \mathrm{Mg}, \mathrm{Al}, \mathrm{Si}, \mathrm{Ca}$, and Fe were significantly

431 larger than the amount derived in $\mathrm{N}_{2}$, especially for $\mathrm{P}$ and $\mathrm{K}$ with 14.9 and 13.7 wt. \%,

432 respectively.

433 The different heating rates have significant influences on the carbon content in char since 434 the $\mathrm{CO}_{2}$ atmosphere could improve the cracking of VOCs and the reaction between VOCs 435 and $\mathrm{CO}_{2}$. The carbon content will increase with the increment of heating rate. In order to 436 investigate the effects of processing time on carbon content of solid residue, the pyrolysis 437 of char which was carried out in the tube furnace (using a simulated TGA process at $5{ }^{\circ} \mathrm{C} / \mathrm{min}$ ) 
438 was conducted under four heating rates in $\mathrm{CO}_{2}$ atmosphere. As the heating rate increased

439 from 5 to $50{ }^{\circ} \mathrm{C} / \mathrm{min}$, the carbon content of cellulose char remained steady at around 93

440 wt. \%, which suggested that $\mathrm{CO}_{2}$ minimally affected the pyrolysis of algal carbohydrate. On

441 the other hand, the carbon content of the newly-prepared char from ovalbumin increased

442 from 15.1 to 29.0 wt. \%. This indicated that $\mathrm{CO}_{2}$ atmosphere would participate in the

443 reaction with carbon contained in char as the pyrolysis progressed, mainly due to the

444 gasification of $\mathrm{CO}_{2}$ and carbon content.

\section{Conclusions}

446 Pyrolysis characteristics of three algal model compounds (cellulose, ovalbumin, oil droplet)

447 and algae (spirulina) were investigated by TGA and analyzed using model free (KAS) and

448 model fitting (Coats-Redfern) methods. It was found that pyrolysis was more efficient at

449 lower heating rates. The algal protein was the first to decompose with the lowest activated

450 energy, followed by carbohydrate and lipid contained in algae. Moreover, $\mathrm{CO}_{2}$ atmosphere

451 favored the pyrolysis of protein due to the improved cracking of VOCs in ovalbumin as well

452 as the reaction between VOCs and $\mathrm{CO}_{2}$. However, the decomposition of lipid and 453 carbohydrate was less feasible in $\mathrm{CO}_{2}$ atmosphere.

\section{Acknowledgement}

455 Following funding bodies are acknowledged for their financial support to this study, 456 National Key R\&D Programme (2017YFB0602601), the Natural Science Foundation China

457 (the Young Scientist Fund) [grant number 5160060426] and Ningbo Bureau of Science and 458 Technology (the Innovation Team Scheme) [grant number 2012B82011]. The International 
459 Doctoral Innovation Centre is also acknowledged for the provision of a full scholarship to 460 the first author. 


\section{Reference}

462 [1] J. Yan, K. Shi, C. Pang, E. Lester, T. Wu, Influence of minerals on the thermal

463 processing of bamboo with a suite of carbonaceous materials, Fuel 180 (2016) 256-

464262.

465 [2] R. Zhang, L. Li, D. Tong, C. Hu, Microwave-enhanced pyrolysis of natural algae

466 from water blooms, Bioresource Technology 212 (2016) 311-317.

467 [3] Q. Xie, M. Addy, S. Liu, B. Zhang, Y. Cheng, Y. Wan, Y. Li, Y. Liu, X. Lin, P. Chen, R.

468 Ruan, Fast microwave-assisted catalytic co-pyrolysis of microalgae and scum for bio-

469 oil production, Fuel 160 (2015) 577-582.

470 [4] D. Beneroso, J.M. Bermudez, A. Arenillas, J.A. Menendez, Microwave pyrolysis of 471 microalgae for high syngas production, Bioresource Technology 144 (2013) 240-246.

472 [5] L. Rodolfi, G. Zittelli, N. Bassi, G. Padovani, N. Biondi, G. Bonini, M. Tredici,

473 Microalgae for Oil: Strain Selection, Induction of Lipid Synthesis and Outdoor Mass

474 Cultivation in a Low-Cost Photobioreactor, Biotechnology \& Bioengineering 102(1)

475 (2009) 100-112.

476 [6] Y. Hong, W. Chen, X. Luo, C. Pang, E. Lester, T. Wu, Microwave-enhanced

477 pyrolysis of macroalgae and microalgae for syngas production, Bioresource

478 Technology 237 (2017) 47-56.

479 [7] R. Sharma, P.N. Sheth, A.M. Gujrathi, Kinetic modeling and simulation: Pyrolysis

480

481

482

483

484

485

486

487

488

489

490

491

492

493

494

495

496

497

498

499 of Jatropha residue de-oiled cake, Renewable Energy 86 (2016) 554-562.

[8] S. Wang, H. Lin, B. Ru, G. Dai, X. Wang, G. Xiao, Z. Luo, Kinetic modeling of biomass components pyrolysis using a sequential and coupling method, Fuel 185 (2016) 763-771.

[9] A. Zaker, Z. Chen, X. Wang, Q. Zhang, Microwave-assisted pyrolysis of sewage sludge: A review, Fuel Processing Technology 187 (2019) 84-104.

[10] R. Maurya, T. Ghosh, H. Saravaia, C. Paliwal, A. Ghosh, S. Mishra, Nonisothermal pyrolysis of de-oiled microalgal biomass: Kinetics and evolved gas analysis, Bioresource Technology 221 (2016) 251-261.

[11] S. Vyazovkin, A unified approach to kinetic processing of nonisothermal data, International Journal of Chemical Kinetics 28(2) (1996) 95-101.

[12] M. Hu, X. Wang, J. Chen, P. Yang, C. Liu, B. Xiao, D. Guo, Kinetic study and syngas production from pyrolysis of forestry waste, Energy Conversion and Management 135 (2017) 453-462.

[13] S. Vyazovkin, A.K. Burnham, J.M. Criado, L.A. Pérez-Maqueda, C. Popescu, N. Sbirrazzuoli, ICTAC Kinetics Committee recommendations for performing kinetic computations on thermal analysis data, Thermochimica Acta 520(1-2) (2011) 1-19. [14] S. Ceylan, D. Kazan, Pyrolysis kinetics and thermal characteristics of microalgae Nannochloropsis oculata and Tetraselmis sp, Bioresource Technology 187 (2015) 15. 
500 [15] S. Ceylan, Y. Topcu, Z. Ceylan, Thermal behaviour and kinetics of alga

501 Polysiphonia elongata biomass during pyrolysis, Bioresource Technology 171(1)

502 (2014) 193-198.

503 [16] C. Gai, Y. Zhang, W.T. Chen, P. Zhang, Y. Dong, Thermogravimetric and kinetic

504 analysis of thermal decomposition characteristics of low-lipid microalgae,

505 Bioresource Technology 150(3) (2013) 139-148.

506 [17] J. Lee, J.-I. Oh, Y.S. Ok, E.E. Kwon, Study on susceptibility of CO2-assisted

507 pyrolysis of various biomass to CO2, Energy 137 (2017) 510-517.

508 [18] L. Tang, Y. Yan, Y. Meng, J. Wang, P. Jiang, C.H. Pang, T. Wu, CO2 gasification

509 and pyrolysis reactivity evaluation of oil shale, Energy Procedia 158 (2019) 1694-

5101699.

511 [19] L. Li, R. Zhang, D. Tong, C. Hu, Fractional Pyrolysis of Algae and Model

512 Compoundst, Chinese Journal of Chemical Physics 28(4) (2015) 525-532.

513 [20] M.T. Cesário, M.M.R. da Fonseca, M.M. Marques, M.C.M.D. de Almeida, Marine

514 algal carbohydrates as carbon sources for the production of biochemicals and

515 biomaterials, Biotechnology Advances 36(3) (2018) 798-817.

516 [21] L. Sheng, X. Wang, X. Yang, Prediction model of biocrude yield and nitrogen

517 heterocyclic compounds analysis by hydrothermal liquefaction of microalgae with

518 model compounds, Bioresource Technology 247 (2018) 14-20.

519 [22] T. Wu, M. Gong, E. Lester, F. Wang, Z. Zhou, Z. Yu, Characterisation of residual

520 carbon from entrained-bed coal water slurry gasifiers, Fuel 86(7-8) (2007) 972-982.

521 [23] J. Oladejo, S. Adegbite, X. Gao, H. Liu, T. Wu, Catalytic and non-catalytic

522 synergistic effects and their individual contributions to improved combustion

523 performance of coal/biomass blends, Applied Energy 211 (2018) 334-345.

524 [24] A.M. Parvez, T. Wu, Characteristics and interactions between coal and

525 carbonaceous wastes during co-combustion, Journal of the Energy Institute 90(1)

526 (2017) 12-20.

527 [25] A.M. Parvez, Y. Hong, E. Lester, T. Wu, Enhancing the Reactivity of Petroleum

528 Coke in $\mathrm{CO} 2$ via Co-Processing with Selected Carbonaceous Materials, Energy and

529 Fuels 31(2) (2017) 1555-1563.

530 [26] A.C.R. Lim, B.L.F. Chin, Z.A. Jawad, K.L. Hii, Kinetic Analysis of Rice Husk Pyrolysis

531 Using Kissinger-Akahira-Sunose (KAS) Method Ø , Procedia Engineering 148 (2016)

532 1247-1251.

533 [27] I. Ali, S.R. Naqvi, A. Bahadar, Kinetic analysis of Botryococcus braunii pyrolysis

534 using model-free and model fitting methods, Fuel 214 (2018) 369-380.

535 [28] L. Tian, A. Tahmasebi, J. Yu, An experimental study on thermal decomposition

536 behavior of magnesite, Journal of Thermal Analysis \& Calorimetry 118(3) (2014)

537 1577-1584. 
561

562

563

564

565

566

567

568

569

570

571

572

573

574

575

[29] S.Y. Yorulmaz, A.T. Atimtay, Investigation of combustion kinetics of treated and untreated waste wood samples with thermogravimetric analysis, Fuel Processing Technology 90(7-8) (2009) 939-946.

[30] Q.V. Bach, W.H. Chen, A comprehensive study on pyrolysis kinetics of microalgal biomass, Energy Conversion \& Management 131 (2017) 109-116.

[31] W.P. Chan, J.-Y. Wang, Characterisation of sludge for pyrolysis conversion process based on biomass composition analysis and simulation of pyrolytic properties, Waste Management 72 (2018) 274-286.

[32] W.P. Chan, J.-Y. Wang, Formation of synthetic sludge as a representative tool for thermochemical conversion modelling and performance analysis of sewage sludge - Based on a TG-FTIR study, Journal of Analytical and Applied Pyrolysis 133 (2018) 97-106.

[33] S.R. Naqvi, R. Tariq, Z. Hameed, I. Ali, M. Naqvi, W.-H. Chen, S. Ceylan, H. Rashid, J. Ahmad, S.A. Taqvi, M. Shahbaz, Pyrolysis of high ash sewage sludge: Kinetics and thermodynamic analysis using Coats-Redfern method, Renewable Energy 131 (2019) 854-860.

[34] A. Plis, J. Lasek, A. Skawińska, J. Zuwała, Thermochemical and kinetic analysis of the pyrolysis process in Cladophora glomerata algae, Journal of Analytical \& Applied Pyrolysis 115 (2015) 166-174.

[35] P. Giudicianni, G. Cardone, R. Ragucci, Cellulose, hemicellulose and lignin slow steam pyrolysis: Thermal decomposition of biomass components mixtures, Journal of Analytical and Applied Pyrolysis 100 (2013) 213-222.

[36] X. Dai, C. Wu, L. Haibin, Y. Chen, The Fast Pyrolysis of Biomass in CFB Reactor, Energy \& Fuels 14(3) (2000) 552-557.

[37] R. Comesaña, M.A. Gómez, M.A. Álvarez, P. Eguía, Thermal lag analysis on a simulated TGA-DSC device, Thermochimica Acta 547 (2012) 13-21.

[38] A.I. Casoni, J. Zunino, M.C. Piccolo, M.A. Volpe, Valorization of Rhizoclonium sp. algae via pyrolysis and catalytic pyrolysis, Bioresource Technology 216 (2016) 302307.

[39] N. Sbirrazzuoli, L. Vincent, A. Mija, N. Guigo, Integral, differential and advanced isoconversional methods: Complex mechanisms and isothermal predicted conversion-time curves, Chemometrics \& Intelligent Laboratory Systems 96(2) (2009) 219-226.

[40] W.P. Chan, J.Y. Wang, Comparison study on thermal degradation behaviours and product distributions for various types of sludge by using TG-FTIR and fixed bed pyrolysis, Journal of Analytical \& Applied Pyrolysis 121 (2016) 177-189.

55 and TGA, Fuel 61(9) (1982) 799-806. 
576 [42] P.E. Amaral Debiagi, M. Trinchera, A. Frassoldati, T. Faravelli, R. Vinu, E. Ranzi,

577 Algae Characterization and Multistep Pyrolysis Mechanism, Journal of Analytical and

578 Applied Pyrolysis (2017).

579 [43] R.N. And, M.J. Antal, Thermal Lag, Fusion, and the Compensation Effect during

580 Biomass Pyrolysist, Industrial \& Engineering Chemistry Research 35(5) (1996) 1711-

5811721.

582 [44] M. Grønli, M.J. Antal, G. Várhegyi, A Round-Robin Study of Cellulose Pyrolysis

583 Kinetics by Thermogravimetry, Industrial \& Engineering Chemistry Research 38(6)

584 (1999) 2238-2244.

585 [45] W. Gao, K. Chen, J. Zeng, J. Xu, B. Wang, Thermal pyrolysis characteristics of

586 macroalgae Cladophora glomerata, Bioresource Technology 243 (2017) 212-217.

587 [46] S. Feng, P. Li, Z. Liu, Y. Zhang, Z. Li, Experimental study on pyrolysis

588 characteristic of coking coal from Ningdong coalfield, Journal of the Energy Institute 589 91(2) (2018) 233-239.

590 